\title{
Aerosol climatology over South Africa based on 10 years of Multiangle Imaging Spectroradiometer (MISR) data
}

\author{
M. Tesfaye, ${ }^{1,2}$ V. Sivakumar, ${ }^{1,2,3}$ J. Botai, ${ }^{1}$ and G. Mengistu Tsidu ${ }^{4}$ \\ Received 28 March 2011; revised 23 June 2011; accepted 12 August 2011; published 29 October 2011.
}

[1] In this paper, we present a detailed study of the spatial and seasonal aerosol climatology over South Africa (SA), based on Multiangle Imaging Spectroradiometer (MISR) data. We have used 10 years (2000-2009) of MISR monthly mean aerosol extinction $\left(\tau_{\text {ext }}\right)$, absorption $\left(\tau_{a}\right)$ optical depths at $558 \mathrm{~nm}$, Angstrom exponents in visible (VIS; 446-672 nm) and near-infrared (NIR; 672-866 nm) spectral bands, and the extracted spectral curvature. The study has shown that, in terms of aerosol load level spatial variation, SA can be classified into three parts: the upper, central, and lower, which illustrate high, medium, and low aerosol loadings, respectively. The results for the three parts of SA are presented in detail. The prevailing sources of aerosols are different in each part of SA. The lower part is dominated by the air mass transport from the surrounding marine environment and other SA or neighboring regions, while the central and upper parts are loaded through windablated mineral dust and local anthropogenic activities. During the biomass burning seasons (July-September), the central part of SA is more affected than the rest of SA by the biomassburning aerosols (based on $\tau_{a}, \sim 20 \%$ higher than the rest of SA). In alignment with the observed higher values of $\tau_{\text {ext }}$, aerosol size distributions were found to be highly variable in the upper part of SA, which is due to the high population and the industrial/mining/ agricultural activities in this area.

Citation: Tesfaye, M., V. Sivakumar, J. Botai, and G. Mengistu Tsidu (2011), Aerosol climatology over South Africa based on 10 years of Multiangle Imaging Spectroradiometer (MISR) data, J. Geophys. Res., 116, D20216, doi:10.1029/2011JD016023.

\section{Introduction}

[2] Atmospheric aerosols originate from various natural and anthropogenic processes. Natural sources include windblown mineral dust, precursor gases from volcanic eruptions, natural wild fires, vegetation, and oceans. Anthropogenic sources include emissions from fossil fuel and biofuel combustion, industrial processes, agriculture practices, humaninduced biomass burning, and photochemically induced smog, primarily due to vehicle emissions [Charlson et al., 1992; Kaufman et al., 1997]. Aerosols are dominant in the troposphere. The lifetime of aerosols varies from minutes to days in the troposphere, due to the prevailing precipitation and interactions with the Earth's surface, depending on aerosol size and chemistry and the height of the atmosphere. Due to unpredictable events such as large dust storms and volcanic eruptions, aerosol concentrations may vary significantly with respect to location and time (diurnal and seasonal variations). Furthermore, aerosols are highly mobile,

\footnotetext{
${ }^{1}$ Department of Geography, Geoinformatics, and Meteorology, University of Pretoria, Pretoria, South Africa.

${ }^{2}$ National Laser Centre, Council for Scientific and Industrial Research, Pretoria, South Africa.

${ }^{3}$ School of Physics, University of KwaZulu Natal, Durban, South Africa.

${ }^{4}$ Department of Physics, Addis Ababa University, Addis Ababa, Ethiopia.

Copyright 2011 by the American Geophysical Union. 0148-0227/11/2011JD016023
}

i.e., they may even cross oceans and mountains. It is generally agreed, that due to various aging processes such as coagulation, humidification, scavenging by precipitation, and gas-to-particle conversion, aerosols often exhibit widely varying physicochemical and optical properties through time [Mallet et al., 2003].

[3] It is also well known that atmospheric aerosols have direct, semidirect, and indirect impacts on the Earth's radiation budget and climate. In addition, aerosols have detrimental effects on human health such as impairment to pulmonary function [Twomey, 1977; Raizenne et al., 1996; Haywood and Boucher, 2000; James et al., 2000; Jayaraman, 2001; Roberts et al., 2001; Intergovernmental Panel on Climate Change, 2007]. However, such effects are determined by the aerosol's optical, physical, and chemical characteristics in concert with source strength and/or advection by local to synoptic meteorological processes. Therefore, measuring and understanding changes in aerosol loading over time are essential to climate prediction. However, studying the impacts of aerosols on climate is challenging, and large uncertainties exist due to the immense diversity, not only with respect to aerosol particle size, composition, sources, and lifetime variation, but also with regard to their spatial and temporal distributions. Thus, the impacts of aerosols on climate must be understood and quantified on a regional scale rather than on a global-average basis [Piketh et al., 2002]. The knowledge of aerosol characteristics at local and global scales and their temporal changes interrelated with other atmospheric parameters and 


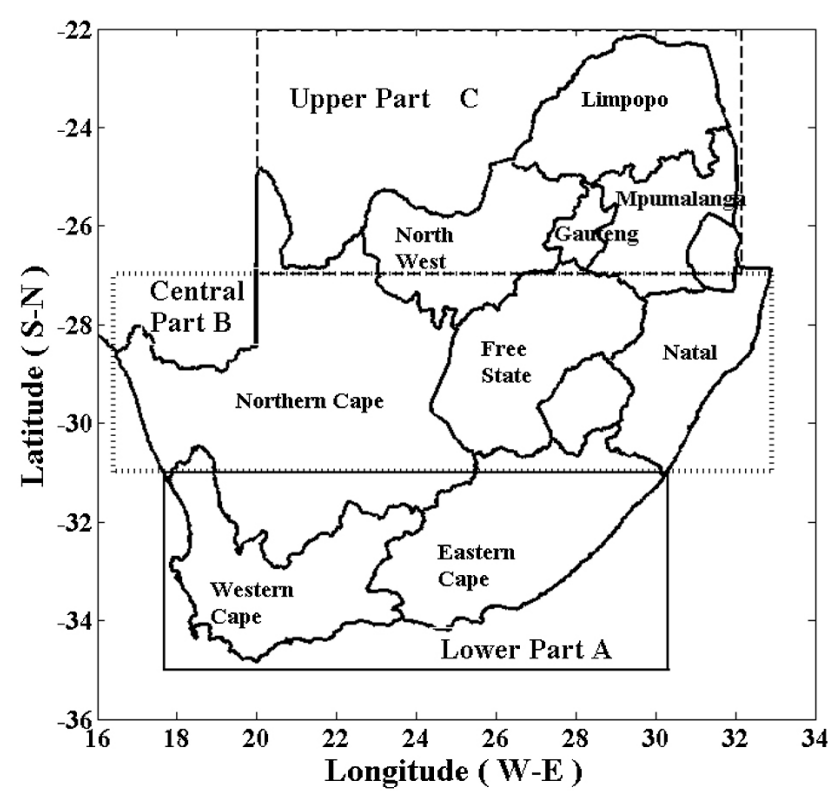

Figure 1. Geographical map of South Africa and our three regional spatial classifications in terms of aerosol load level differences.

solar radiation are of great importance for the study on the effects of aerosols in the atmosphere. Improved aerosol climatology may enable more accurate estimations of the direct and indirect aerosol forcing [Kaufman et al., 1997; Masmoudi et al., 2003]. Aerosol parameters can be measured in situ or remotely sensed from the ground or from aircraft or satellites [Sivakumar et al., 2010]. In particular, satellite-based aerosol observation constitutes a recent and powerful tool for assessing aerosol spatial distribution and their properties. In some cases, due to its ability of providing a complete and synoptic view, large areas can be assessed in single snapshots. The data from satellite sensors can be used to improve the current understanding of climate prediction and the impacts of aerosols on climate change [Holben et al., 1992; Kaufman, 1993; Kaufman et al., 2002; King et al., 1999; Ignatov and Stowe, 2002; Levy et al., 2003, 2009; Kahn et al., 2009].

[4] South Africa (SA) is located at the southernmost tip of the African continent, with geocoordinates extending from $22^{\circ} \mathrm{S}$ to $34^{\circ} \mathrm{S}$ latitude and from $16^{\circ} \mathrm{E}$ to $32^{\circ} \mathrm{E}$ longitude (see Figure 1). SA shares borders with Namibia, Botswana, Zimbabwe, and Mozambique. South Africa is famous for its brilliant orange skies at sunrise and sunset, which may also be an indicator of the presence of aerosols. Some previous studies have indicated that SA is one of the most affected countries with regard to aerosol load, due to various natural and anthropogenic activities [e.g., Piketh et al., 1999, 2002; Formenti et al., 2002, 2003; Campbell et al., 2003; Eck et al., 2003; Freiman and Piketh, 2003; Ichoku et al., 2003; Ross et al., 2003; Liu, 2005; Winkler et al., 2008; Queface et al., 2011]. Those studies focused on a limited time scale, during biomass-burning seasons, and on the northern parts of SA, where $\sim 75 \%$ of the country's industrial infrastructure is concentrated and which is populated by coal-fired power plants.
[5] Multiangle Imaging Spectroradiometer (MISR) provides useful information for scientists studying different aspects related to the Earth's climate, such as the partitioning of energy and carbon between the land surface and the atmosphere, and the regional/global impacts of different types of atmospheric particles (aerosols) and clouds on climate [Diner et al., 1998, 2001, 2005; Kahn et al., 2001, 2005; Martonchik et al., 2004; Kalashnikova and Kahn, 2008; Dey and Di Girolamo, 2010]. The present work aims to report the seasonal and spatial variation of aerosol optical and microphysical properties over the entire SA region, based on 10 years (2000-2009) of MISR data. In addition, by correlating the variation of aerosol optical properties and background weather parameters such as rainfall, relative humidity $(\mathrm{RH})$, and wind speed (obtained from the South African Weather Service (SAWS)), the effects of local meteorological conditions on the aerosol optical, microphysical properties and their dynamics (load, dispersion, and removal processes) are evaluated. The paper is organized as follows: Section 2 provides information about MISR, as well as data and analysis, including meteorological data. Section 3 presents results obtained in terms of the spatial-seasonal variability of the observed aerosol optical parameters in association with background weather conditions, by classifying SA into three regions. Finally, section 4 provides a summary and concluding remarks.

\section{Data and Methods}

\subsection{MISR Data and Analysis}

[6] MISR was launched by National Aeronautics and Space Administration (NASA) on 18 December 1999 and has been in operation since February 2000. The device is designed to measure solar radiation reflected by the Earth's system (planetary surface and atmosphere) in various angular positions. It consists of nine push broom cameras arranged to view at nominal zenith angles relative to the surface reference ellipsoid of $0.0^{\circ}, \pm 26.1^{\circ}, \pm 45.6^{\circ}, \pm 60.0^{\circ}$ and $\pm 70.5^{\circ}$ and measures upwelling short wave radiance in each camera at four spectral bands, centered at 446, 558, 672, and $866 \mathrm{~nm}$. This makes MISR unique among the NASA Earth-observing system Terra satellite instruments, by providing radiometrically and geometrically accurate and carefully calibrated high spatial resolution image data. The multiple angle band observations of MISR further allow us to retrieve a number of aerosol optical and microphysical properties over land (including bright desert surfaces) and ocean, as well as surface albedo and information about cloud properties [Diner et al., 1998, 1999, 2001, 2005; Martonchik et al., 1998, 2002, 2004; Kahn et al., 2001, 2007; Muller et al., 2002; Kalashnikova et al., 2005; Kalashnikova and Kahn, 2006]. More detailed information about the instrument and the data is available at http://eosweb.larc.nasa.gov/GUIDE/ campaign_documents/misr_ov2.html.

[7] Optical properties of aerosols may be described using a number of parameters. The spectral aerosol extinction optical depth (AOD; $\left.\tau_{\text {ext }}\left(\lambda_{i}\right)\right)$ is the vertical integral of fraction of incident light either scattered or absorbed by airborne particles (i.e., the sum of aerosol scattering optical depth $\tau_{s}\left(\lambda_{i}\right)$ and aerosol absorption optical depth $\tau_{a}\left(\lambda_{i}\right)$. AOD is an indicator of the aerosol load level in the vertical column of the 
atmosphere and constitutes important parameters used to assess the aerosol radiative forcing and its impact on climate [Charlson et al., 1992; Hansen et al., 1997, and references therein; Eck et al., 1999; Cachorro et al., 2001; Holben et al., 2001; Christopher and Zhang, 2002]. The MISR-AOD Level 3 data have a higher grid resolution $\left(0.5^{\circ} \times 0.5^{\circ}\right)$ in comparison to the Moderate Resolution Imaging Spectroradiometer (MODIS) Level 3 data which have a resolution of $1^{\circ} \times 1^{\circ}$. Further, earlier studies revealed that the MISRretrieved AOD has better agreement with ground-based Aerosol Robotic Network (AERONET) measurements, when compared with MODIS [Diner et al., 2001; Christopher and Wang, 2004; Liu et al., 2004; Martonchik et al., 2004; Abdou et al., 2005; Kahn et al., 2005, 2007, 2010; Jiang et al., 2007; Prasad and Singh, 2007; de Meij and Lelieveld, 2011]. In the present study, we have used the latest version (version 31) of MISR Level 3 monthly averaged global $0.5^{\circ} \times 0.5^{\circ}$ grid data of aerosol extinction and absorption optical depth at $558 \mathrm{~nm}$.

[8] The sensitivity of the particle extinction efficiency to wavelength, i.e., $\left|\partial Q_{\text {ext }}(\lambda, r) / \partial \lambda\right|$, generally increases with decreasing particle size. This sensitivity is true for any particle composition and may easily be demonstrated using the Mie algorithm. An empirical measure of this sensitivity is obtained from spectral values of AOD at two different wavelengths, $\lambda_{1}$ and $\lambda_{2}$, expressed through Angstrom's empirical relationship [Angstrom, 1929]:

$$
\alpha=\frac{\ln \left[\frac{\tau_{\text {ext }}\left(\lambda_{1}\right)}{\tau_{\text {ext }}\left(\lambda_{2}\right)}\right]}{\ln \left[\frac{\lambda_{1}}{\lambda_{2}}\right]} .
$$

Using the MISR Level 3 monthly global $0.5^{\circ} \times 0.5^{\circ}$ grid AOD data at 446, 672, and $866 \mathrm{~nm}$ in equation (1), we compute the Angstrom exponent $(\alpha)$ in the visible (VIS; 446$\left.672 \mathrm{~nm}, \alpha_{(446-672) \mathrm{nm}}\right)$ and near-infrared (NIR; 672-866 nm, $\left.\alpha_{(672-866) \mathrm{nm}}\right)$ spectral bands. The values of both aerosol optical parameters (AOD and $\alpha$ ) exhibit a strong dependence on the amount of aerosols of different sizes and concentrations, their chemical composition, and the wavelength of the incident radiation [Eck et al., 1999, 2001, 2003; Reid et al., 1999; Cachorro et al., 2001; O'Neill et al., 2001a, 2001b, 2002, 2003; Adeyewa and Balogun, 2003]. Therefore, they are widely used in atmospheric sciences dealing with optical properties of aerosol particles. The Angstrom exponent is commonly used to provide further information on particle size distribution of aerosols in the solar spectrum. Several authors have discussed how the spectral variation of $\alpha$ can provide information about the aerosol size distribution [e.g., Nakajima et al., 1986; Kaufman et al., 1992; Eck et al., 1999; Reid et al., 1999; O'Neill et al., 2001a, 2001b, 2002, 2003; Kaskaoutis and Kambezidis, 2006; Schuster et al., 2006]. Values of $\alpha$ exceeding 1.5 indicate size distributions dominated by fine-mode aerosols, radii $\leq 0.35 \mu \mathrm{m}$ ) that are usually associated with urban pollution (sulfate) and biomass burning (carbonaceous aerosols), whereas, $\alpha$ values between 1 and 1.5 indicate the presence of accumulation-mode particles $(0.35 \mu \mathrm{m}<$ radii $\leq 0.75 \mu \mathrm{m})$. Values of $\alpha<1$ indicate size distributions dominated by coarse-mode aerosols (radii $>0.75 \mu \mathrm{m}$ ) (sea spray and large dust particles), especially for larger aerosol particles such as desert dust particles, $\alpha$ approaches zero. Generally, a very high $\alpha$ values at shorter wavelength intervals (UV and VIS bands), indicates the presence of submicron (fine and accumulation) particles probably resulting from various anthropogenic activities, with less influence of the supermicron (coarse) particles. In contrast, observing low values of $\alpha(<1)$ at longer wavelength regions implies the existence of supermicron (coarse) particles. However, the studies by Eck et al. [1999, 2001] and Reid et al. [1999] revealed high values of $\alpha(>1.4)$ at longer wavelength with an increase in AOD, resourced due to the presence of submicron particles which are induced by extensive biomass-burning activities. Thus, in our present study, we have also included $\alpha$ in the longer wavelength range (NIR) for a better understanding of biomass-burning seasons in SA.

[9] On the other hand, King and Byrne [1976] and Eck et al. [1999] inferred a large deviation in the linear fit of measured AOD and wavelength. These studies also addressed that the addition of the first derivative of $\alpha$ (i.e., $\alpha^{\prime}$ ) into $\ln \tau_{\text {ext }}(\lambda)$ versus $\ln \lambda$ relationship provide a better result. Additionally, previous studies have indicated the inadequacies of the Angstrom exponent values in providing the relative fractional contribution of supermicron and submicron particles to the total AOD [King et al., 1978; Kaufman, 1993; Eck et al., 1999, 2001, 2003; O'Neill et al., 2001a, 2001b, 2003; Gobbi et al., 2007; Basart et al., 2009, and references therein]. Further, the above studies have also suggested the importance of the spectral curvature of the Angstrom exponent $\left(\alpha^{\prime}\right)$ together with $\alpha$ for providing more information on the aerosol size distribution. Therefore, in the present study, we have determined the $\alpha$ in both wavelength regions (VIS and NIR) and $\alpha^{\prime}$ for a more comprehensive understanding of the relative contribution of different modes of aerosols to the total AOD. In general, $\alpha^{\prime}$ can be expressed as

$\alpha^{\prime}=\frac{d \alpha}{d \ln \lambda}=-\left(\frac{2}{\ln \lambda_{i+1}-\ln \lambda_{i-1}}\right)\left[\frac{\ln \tau_{i+1}-\ln \tau_{i}}{\ln \lambda_{i+1}-\ln \lambda_{i}}-\frac{\ln \tau_{i}-\ln \tau_{i-1}}{\ln \lambda_{i}-\ln \lambda_{i-1}}\right]$

In this work, equation (2) is represented as $\Delta \alpha=\alpha_{(446-672) \mathrm{nm}}-$ $\alpha_{(672-866) \mathrm{nm}}$, and following the work of several authors [e.g., Kaufman, 1993; Eck et al., 1999, 2001; Reid et al., 1999; O'Neill et al., 2001a, 2001b, 2003; Gobbi et al., 2007; Basart et al., 2009],we have used it to extract additional information about aerosol size distributions such as the relative dominant influence of coarse-mode versus submicron-mode aerosol fractions or the effect of two particle modes on the aerosol size distribution. The large positive values of $\alpha^{\prime}$ (along with $\alpha<1$ ) are characteristic of coarse-mode-dominated, bimodal aerosol size distributions. While, the near zero (along with $1<\alpha<1.3$ ) or negative (along with $\alpha>1.3$ ) values of $\alpha^{\prime}$ are respectively characteristic of accumulation or fine-mode-dominated aerosol size distributions.

\subsection{Meteorological Data}

[10] The meteorological parameters such as RH, rainfall, and wind speed have a detrimental impact in aerosol dynamics (load, dispersion, and removal processes) and various aging processes (physicochemical change) [Mallet et al., 2003]. Thus, in order to assess the impacts of the background weather conditions on the spatial-seasonal variability aerosol optical and microphysical properties over SA, 

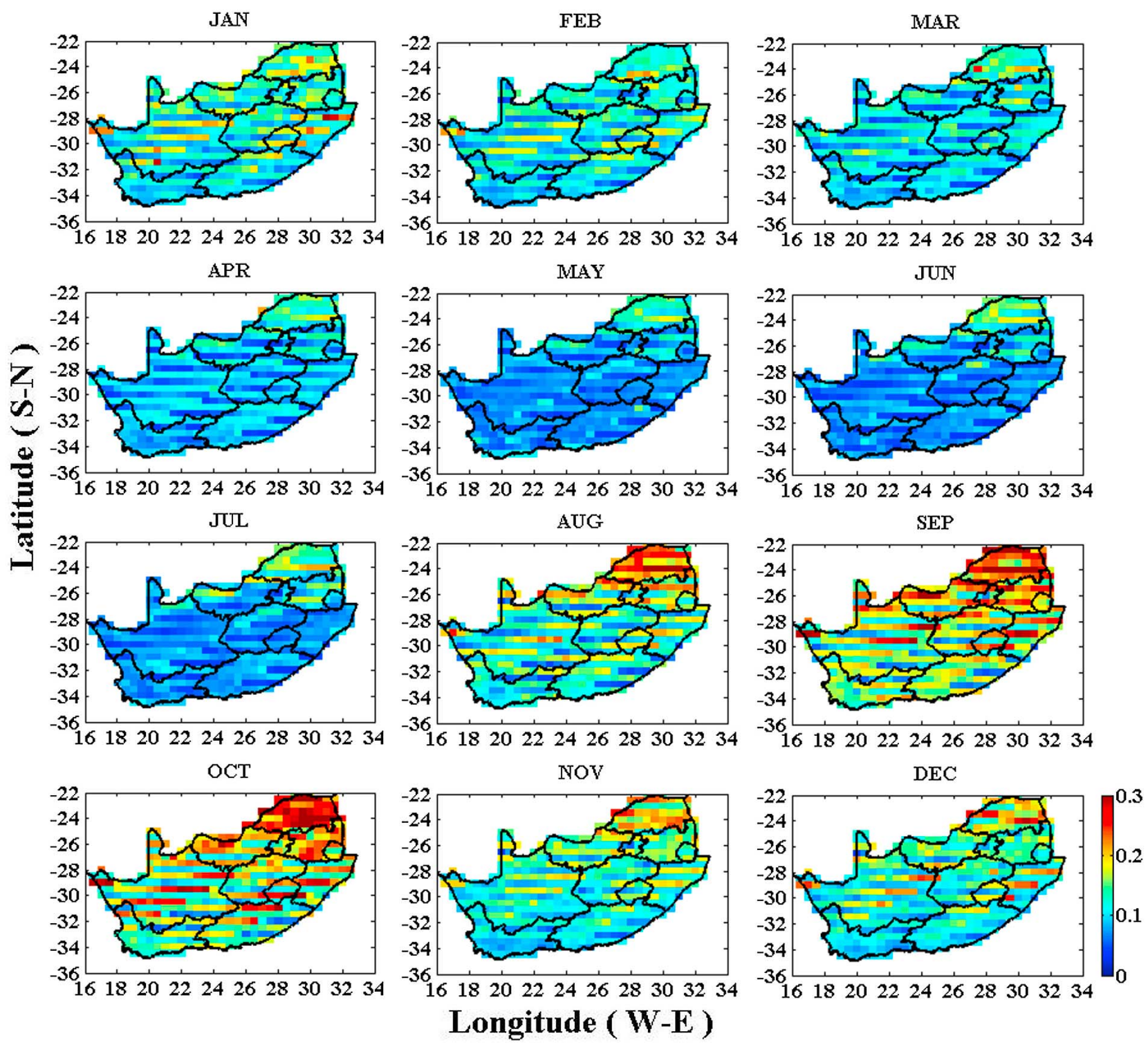

Figure 2a. Averaged aerosol extinction optical depth over South Africa obtained from 10 years of MISR data.

we have used local meteorological parameters together with the MISR data. Here, we have used the monthly mean based on 10 years (2000-2009) of archival meteorological data of RH, rainfall, wind speed, and wind direction from nine SAWS stations: Cape Town $\left(33.9^{\circ} \mathrm{S}, 18.6^{\circ} \mathrm{E}\right)$, East London $\left(33.0^{\circ} \mathrm{S}, 27.8^{\circ} \mathrm{E}\right)$, Durban South $\left(29.9^{\circ} \mathrm{S}, 30.9^{\circ} \mathrm{E}\right)$, Bloemfontein $\left(29.1^{\circ} \mathrm{S}, 26.3^{\circ} \mathrm{E}\right)$, Upington $\left(28.4^{\circ} \mathrm{S}, 21.3^{\circ} \mathrm{E}\right)$, Johannesburg $\left(26.2^{\circ} \mathrm{S}, 28.2^{\circ} \mathrm{E}\right)$, Ermelo $\left(26.5^{\circ} \mathrm{S}, 29.9^{\circ} \mathrm{E}\right)$, Mafikeng $\left(25.8^{\circ} \mathrm{S}, 25.5^{\circ} \mathrm{E}\right)$, and Polokwane $\left(23.9^{\circ} \mathrm{S}, 29.5^{\circ} \mathrm{E}\right)$.

\section{Results and Discussion}

\subsection{General Aerosol Seasonal Characteristics}

[11] Ten years of monthly averaged aerosol optical parameters $\left(\tau_{\operatorname{ext}(558 \mathrm{~nm})}, \tau_{a(558)}, \alpha_{(446-672) \mathrm{nm}}, \alpha_{(672-866) \mathrm{nm}}\right.$ and $\left.\alpha^{\prime}\right)$ are presented in Figures 2a-2e. Figure 2a shows the aerosol extinction optical depth at $558 \mathrm{~nm}\left(\tau_{\operatorname{ext}(558 \mathrm{~nm})}\right)$. It is evident from Figure 2 that the maximum values $\left(\tau_{\operatorname{ext}(558 \mathrm{~nm})}>0.25\right)$ are observed during spring (August-October) and minimum values $\left(\tau_{\operatorname{ext}(558 \mathrm{~nm})}<0.25\right)$ during winter (May-July). It is also interesting to note a significant decrease in $\tau_{\text {ext(558 nm) }}$ ( $30 \%$ ) during the May to July period in comparison with the other months (see Figure 2a). Such a decrease in AOD might be due to consequential results of cloud scavenging and wet removal processes of the summer months followed by low wind speed and low water vapor atmospheric weather conditions which cause respectively weak generation mechanisms and a remote chance of hygroscopic growth of aerosols. Similar seasonal variations of AOD have been reported by Formenti et al. [2002] and Queface et al. [2011], who have used measurements from the South African Astronomical Observatory at Sutherland $\left(32.2^{\circ} \mathrm{S}, 20.5^{\circ} \mathrm{E}\right)$ and Sun photometer measurements from Skukuza $\left(\sim 24.6^{\circ} \mathrm{S}, 31.35^{\circ} \mathrm{E}\right)$ (an AERONET site). 

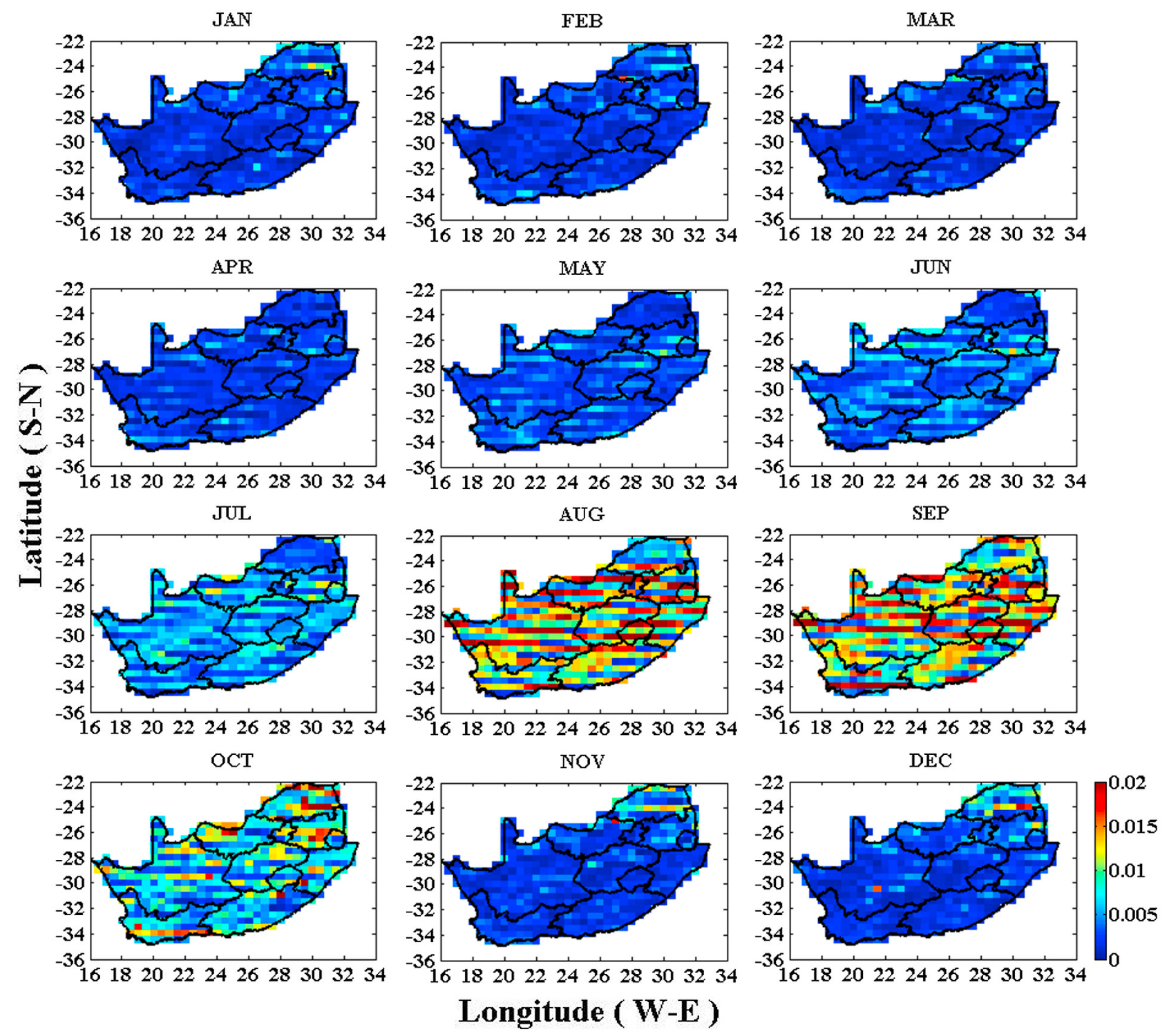

Figure 2b. Same as Figure 2a but for aerosol absorption optical depth.

[12] In order to study the seasonal and spatial variation of absorbing aerosol loads, such as aerosols from biomass burning and urban/industrial activities, the aerosol absorption optical depth $\left(\tau_{a(558 \mathrm{~nm})}\right)$ is plotted in Figure $2 \mathrm{~b}$. It is evident from Figure 2 that $\tau_{a(558 \mathrm{~nm})}$ shows a minimum value ( 0.002) during summer and early winter (November-May), except in the northern part which shows slightly higher values. Thereafter, there is a steady increase in $\tau_{a(558 \mathrm{~nm})}$ values from June, with a maximum value during the month of September. Overall, the maximum absorbing aerosol load is inferred during spring (August-October). The observed rise in $\tau_{a(558 \mathrm{~nm})}$ during June and July might be due to the air mass transport from tropical regions of southern Africa [Freiman and Piketh, 2003] where biomass-burning activities also happen during the same time period [Magi et al., 2009]. However, the observed increase in $\tau_{a(558 \mathrm{~nm})}$ during spring is attributed to the local pronounced biomass-burning activities in the northeastern and eastern part of SA, in addition to a minor contribution by long-range transported biomassburning aerosols from across the border countries, i.e., Namibia, Zimbabwe, and Botswana. Concurrently, we also observed a seasonal peak in AOD during spring (see Figure 2a).

[13] The spatial variation of $\tau_{\operatorname{ext}(558 \mathrm{~nm})}$ indicates that different provinces in SA have different aerosol loading levels. The provinces, North West, Gauteng, Mpumalanga and Limpopo (see Figure 1 for locations) are highly polluted in comparison to upper part of Northern Cape, Free State, and Natal (modestly polluted) and to Western Cape, Eastern Cape, and the lower part of Northern Cape (low pollution). The above spatial variations might be due to the variations in long-range aerosol transportation, different aerosol sources and/or source strength and local meteorological parameters, such as RH, rainfall, and wind speed. Details on 

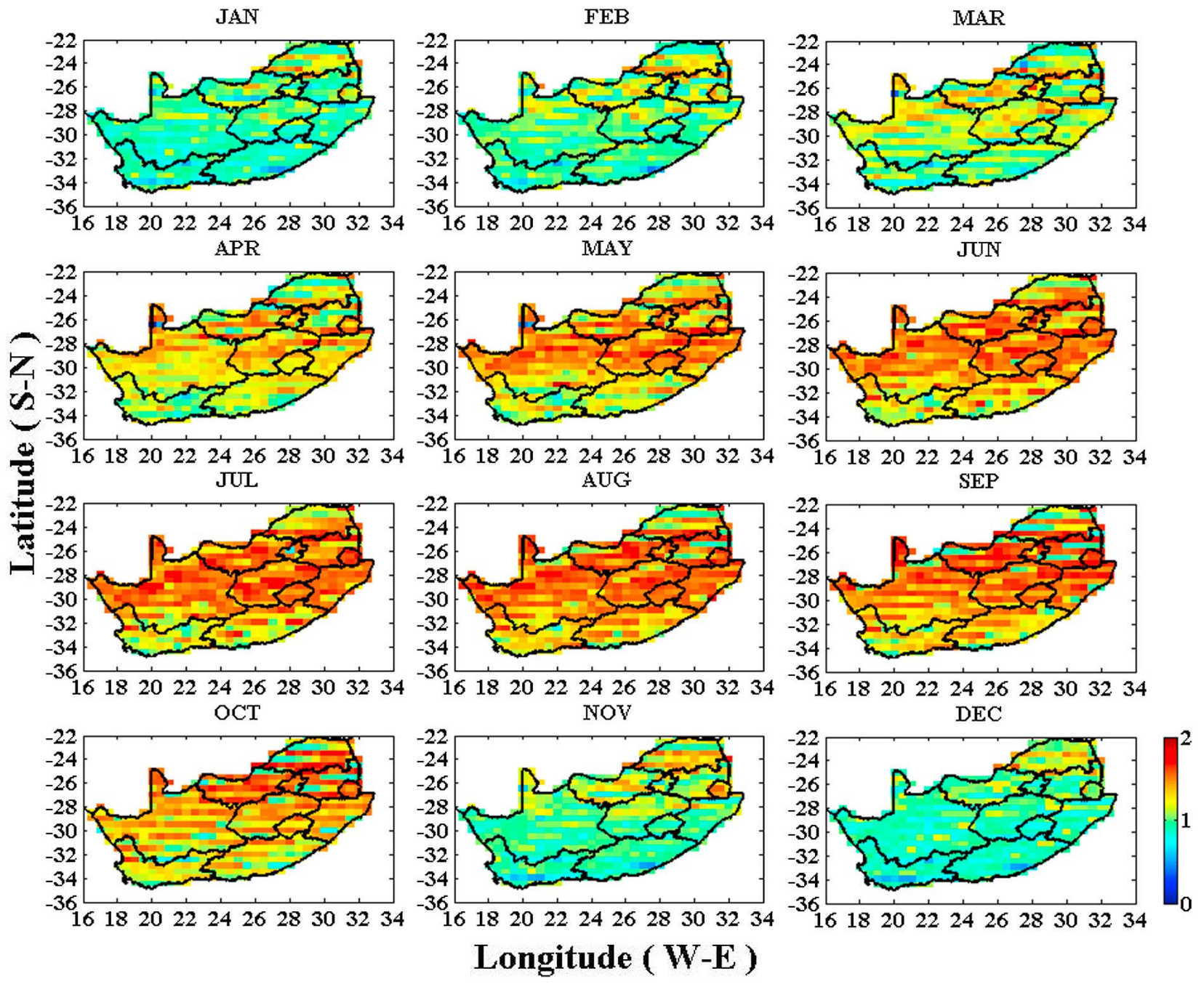

Figure 2c. Same as Figure 2a but for Angstrom exponent over visible region.

the relationship between the spatial and seasonal variability of AOD and local meteorological parameters are discussed in section 3.2.

[14] The Angstrom exponent values in the VIS $\left(\alpha_{(446-672) \mathrm{nm}}\right)$ and NIR $\left(\alpha_{(672-866)} \mathrm{nm}\right)$ bands are plotted in Figures $2 \mathrm{c}$ and $2 \mathrm{~d}$, respectively. During the dry seasons (winter to spring period, i.e., May-October) the Angstrom exponent values vary from 0.85 to 1.89 and from 0.74 to 1.95 in the VIS and NIR bands, respectively. As described in section 2, in order to extract the relative dominant particle mode in the aerosol size distribution, we have calculated $\alpha^{\prime}$ (see Figure 2e). It is noted from Figure 2 that during this period (May-October), $\alpha^{\prime}$ shows a lower value (from -0.25 to 0.41 ) with the exception of the Western Cape and Eastern Cape provinces. The above observed values of $\alpha$ and $\alpha^{\prime}$ indicate that the South African atmosphere is dominantly loaded by a mixture of accumulation-mode and fine-mode particles. However, the obtained results indicate that the accumulation-mode particles in the aerosol size distribution prevail slightly (as $\alpha^{\prime}$ indicates slightly more positive than negative). The observed higher values of $\alpha_{(672-866) \mathrm{nm}}$ (from 1.25 to 1.73 ), especially in most areas of the Northern Cape, Free State, and Natal provinces, indicate the presence of submicron particles, which are mainly due to biomass burning and urban/industrial activities. During the summer to autumn period (NovemberApril), the Angstrom exponent varies from 0.56 to 1.64 and from 0.41 to 1.51 in the VIS and NIR bands, respectively. In addition, over most regions of SA, the $\alpha^{\prime}$ value varies from 0.24 to 1.06 (see Figure 2e). The above values indicate that during this period, the South African atmosphere is dominantly loaded with a mixture of accumulation-mode and coarse-mode aerosols. However, during November to January, the $\alpha$ value for most regions of SA varies from 0.41 to 1.20 and $\alpha^{\prime}$ varies from 0.42 to 1.06 . This indicates that the coarse-mode particles are higher than the accumulationmode particles in the aerosol size distribution. All the above results on seasonal variation of $\tau_{\operatorname{ext}(558 \mathrm{~nm})}, \tau_{a(558 \mathrm{~nm})}$, $\alpha_{(446-672) \mathrm{nm}}, \alpha_{(672-866) \mathrm{nm}}$ and $\alpha^{\prime}$ are found to be in good agreement with earlier published reports, though their results are focused on a particular region/part of SA, based on in situ, satellite, ground based, and air mass trajectory observations [Piketh et al., 1999; Formenti et al., 2002, 2003; Eck et al., 2003; Freiman and Piketh, 2003; Ross et al., 2003; Liu, 2005; Magi et al., 2009; Queface et al., 2011]. Details on 

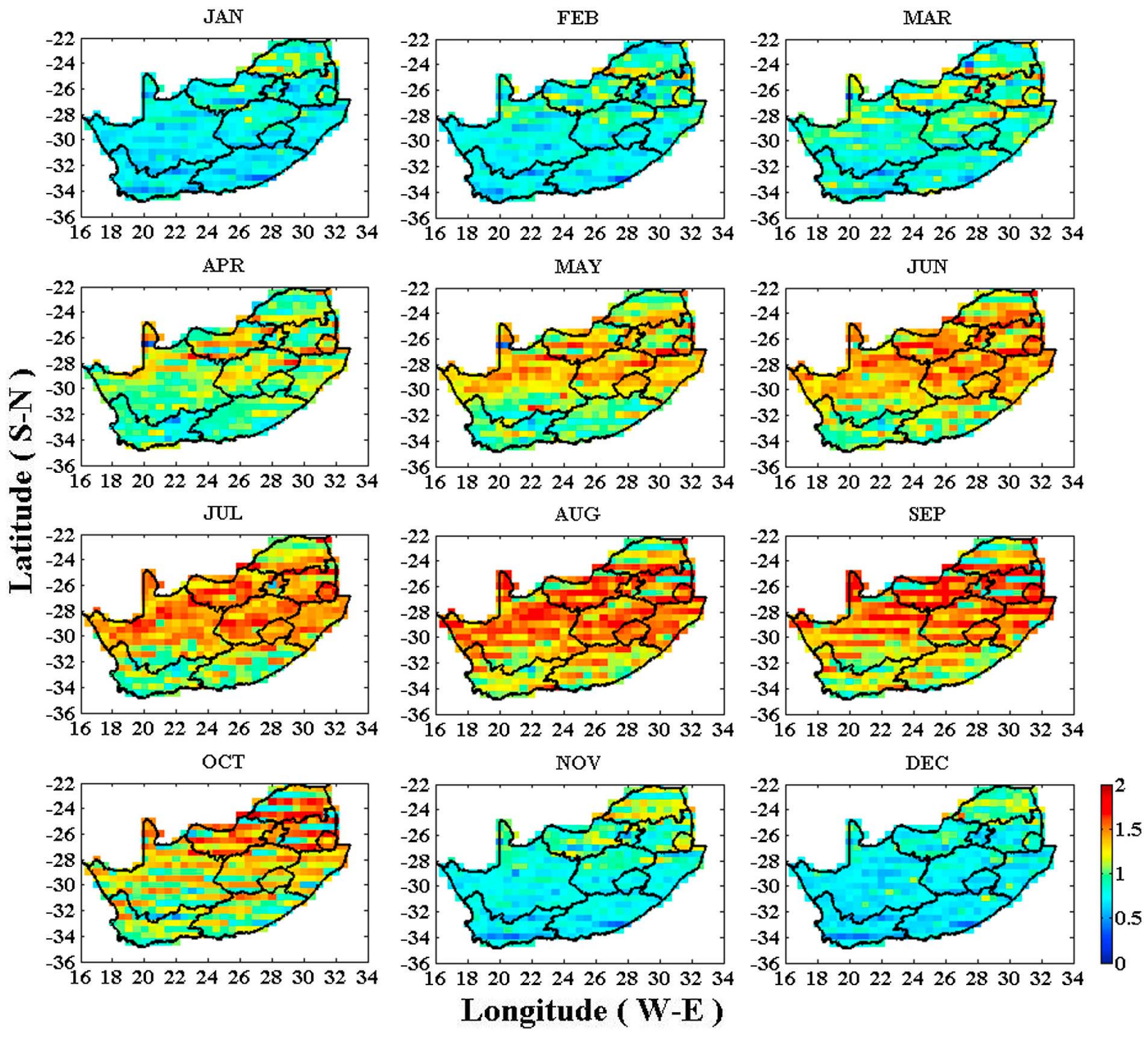

Figure 2d. Same as Figure 2a but for Angstrom exponent over NIR region.

the spatial and seasonal variability of aerosol size distribution correlated with local meteorological parameters are discussed in section 3.2.

[15] The above results confirm that different regions in SA have different aerosol loading levels and significant seasonal variations of aerosol radiative properties and their size distribution. Therefore, based on the above information, we have spatially classified SA into three broad regions: (1) lower part $\left(35^{\circ} \mathrm{S}\right.$ to $31^{\circ} \mathrm{S} ; 17.5^{\circ} \mathrm{E}$ to $\left.30.5^{\circ} \mathrm{E}\right)$, includes the Western Cape, Eastern Cape, and lower parts of the Northern Cape (Figure 1, box A); (2) central part $\left(31^{\circ} \mathrm{S}\right.$ to $27^{\circ} \mathrm{S}, 16.5^{\circ} \mathrm{E}$ to $\left.33^{\circ} \mathrm{E}\right)$, includes the middle and upper part of the Northern Cape, Free State, and Natal provinces (Figure 1, box B); and (3) upper part $\left(27^{\circ} \mathrm{S}\right.$ to $22^{\circ} \mathrm{S}, 19.5^{\circ} \mathrm{E}$ to $\left.32^{\circ} \mathrm{E}\right)$, includes North West, Gauteng, Mpumalanga, and Limpopo provinces (Figure 1, box $\mathrm{C}$ ). This spatial classification interrelated with other local meteorological parameters allows us to handle large data sets efficiently for understanding the aerosol climatology over
SA. The aerosol climatological results presented in this paper follow the above spatial classification.

\subsection{The Seasonal Aerosol Climatology Over Different Parts of South Africa}

[16] For each part of SA (lower, central, and upper), the monthly variations of AOD versus wind speed and $\alpha, \alpha^{\prime}$ versus RH, are given in Figures 4, 5, and 6. Figures 4, 5 , and 6 are plotted from January to December, to represent the results in terms of different seasons: summer (November-February), early winter (March-April), winter (May-July) and early summer (August-October). The obtained results are described in detail in sections 3.2.1-3.2.3.

\subsubsection{Lower Part of South Africa}

[17] The lower part of SA is surrounded by the Atlantic and Indian oceans. The ocean regions are one of the major sources of natural marine aerosols. Marine aerosols are composed of (1) primary aerosols, which are generated at the sea surface 

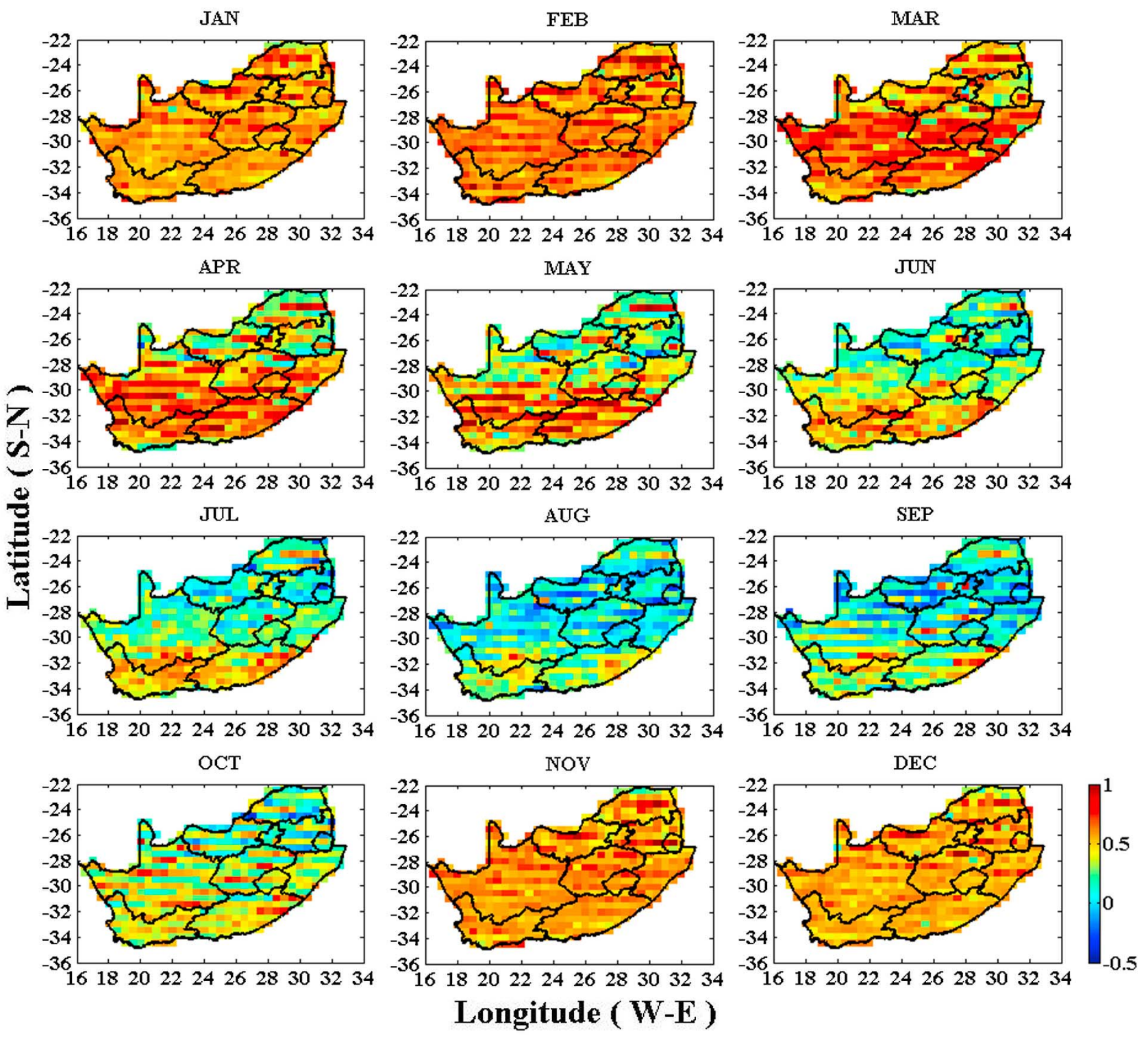

Figure 2e. Same as Figure 2a but for Angstrom exponent spectral curvature.

through wind driven processes, and (2) secondary aerosols, through gas-to-particle conversion processes [O'Dowd and de Leeuw, 2007]. Marine aerosols contribute to both finemode and coarse-mode particles, with dominant fractions of inorganic sea-salt and organic particles in the supermicron and submicron modes, respectively [Latham and Smith, 1990; Kaufman et al., 2002; Cavalli et al., 2004].

[18] Figure 4a shows the monthly mean variation of AOD and wind speed (surface) for the lower part of the SA. It is clear from Figure 4a that the AOD and wind speed follow a similar pattern of annual oscillation (AO) with a minimum during June. The maximum AOD is recorded during September and is almost twice the minimum. High wind speed is observed during December (a summer month with high rainfall; see Figure 3). We have also plotted $\alpha$ in the VIS and NIR, and $\alpha^{\prime}$ and RH (see Figure 4b) for the same period, as presented in Figure 4a. The $\alpha$ values in both the spectral bands show a similar trend, with higher values in the VIS than the NIR band (as expected). The order of separation $(\alpha)$ between the VIS and NIR bands is $\sim 0.2$ and is lower during August and September ( 0.1). Both the spectral bands show a minimum and maximum value recorded for December and August. The observed RH is related to the seasonal variations of $\alpha$, with a maximum during winter (including August) and a minimum during summer. A more detailed discussion on the seasonal variations of AOD, $\alpha$ and their interrelations follows.

[19] It is evident from Figures $4 \mathrm{a}$ and $4 \mathrm{~b}$ that the AOD declines together with the southeasterly wind speed during summer (November-February) and $\alpha$ values for VIS and NIR spectral bands vary from 0.72 to 1.06 and from 0.55 to 0.83 respectively. At the same time, the $\alpha^{\prime}$ ranges from 0.42 to 0.92 (see Figure $4 b$ ), indicating that, during this season in the lower part of SA, the aerosol size distribution in both spectral bands are dominated by coarse-mode aerosols rather than accumulation-mode aerosols. In general, summer in the 


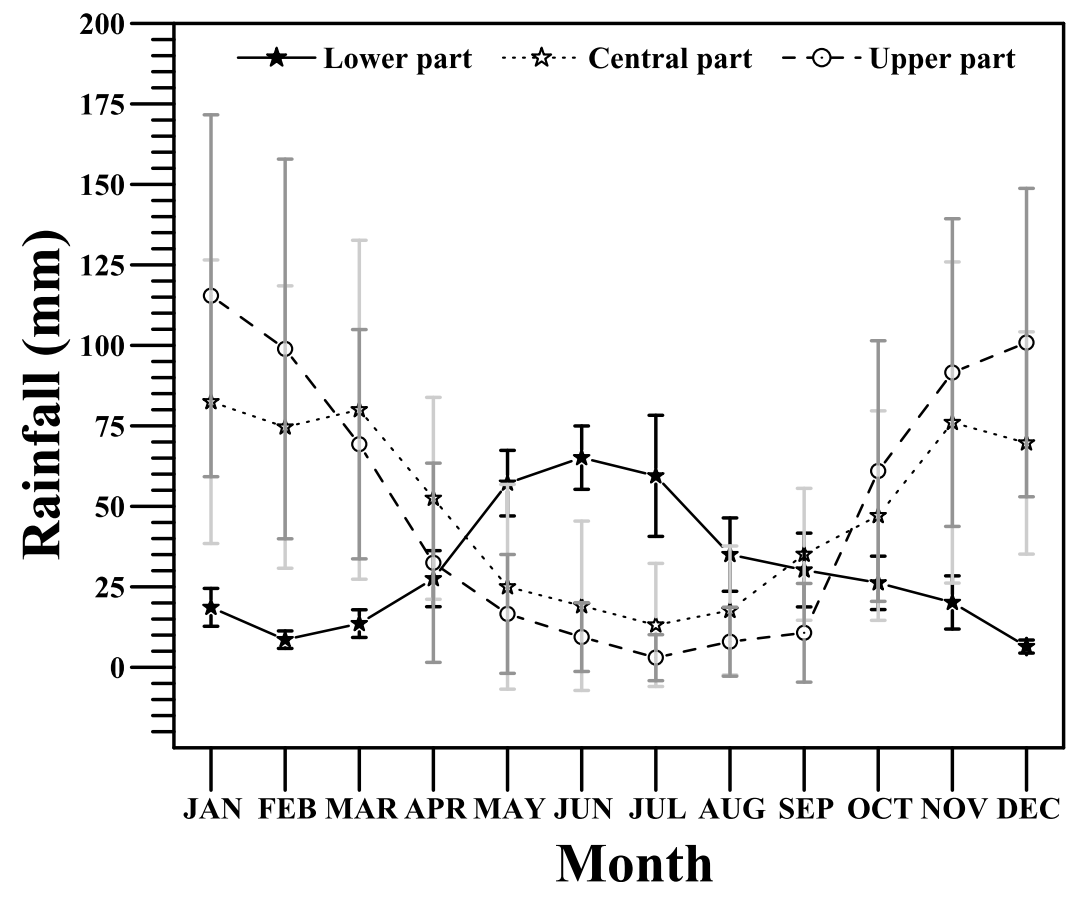

Figure 3. Monthly mean rain fall and standard deviation obtained from 10 years of data for different parts of South Africa. Lower part: Cape Town $33.9^{\circ} \mathrm{S}, 18.6^{\circ} \mathrm{E}$ and East London $33.0^{\circ} \mathrm{S}, 27.8^{\circ} \mathrm{E}$. Central part: Durban South $29.9^{\circ} \mathrm{S}, 30.9^{\circ} \mathrm{E}$, Bloemfontein $29.1^{\circ} \mathrm{S}, 26.3^{\circ} \mathrm{E}$, and Upington $28.4^{\circ} \mathrm{S} 21.3^{\circ} \mathrm{E}$. Upper part: Johannesburg $26.2^{\circ} \mathrm{S}, 28.2^{\circ} \mathrm{E}$, Ermelo $26.5^{\circ}, 29.9^{\circ} \mathrm{E}$, Mafikeng $25.8^{\circ} \mathrm{S}, 25.5^{\circ} \mathrm{E}$, and Polokwane $23.9^{\circ} \mathrm{S} ; 29.5^{\circ} \mathrm{E}$.

lower part of SA has less rain (see Figure 3), low RH, and strong southeasterly winds which bring cool air from the sea. During this period, the significant contribution of coarsemode aerosols over this area might be explained as follows. The ground of the lower part of SA is not particularly dusty and, hence, there is only limited local aerosol generation due to wind ablation of mineral dust particles. On the other hand, a change in AOD due to a change in wind-induced, marine, coarse-mode aerosols' size distribution is well established by various researchers [e.g., Hoppel et al., 1990; O'Dowd and Smith, 1993; Gong et al., 1997; O'Dowd et al., 1997; O'Dowd and de Leeuw, 2007; Lehahn et al., 2010]. Lehahn et al. [2010] reported that, on average, the threshold value of surface wind speed for triggering emission of maritime aerosols is $4.1 \pm 0.1 \mathrm{~m} / \mathrm{s}$. When wind speed exceeds the threshold value, the coarse-mode marine aerosols' optical depth is linearly correlated to the surface wind speed, with a consistent slope of $0.009 \pm 0.002 \mathrm{~m} / \mathrm{s}$ [Lehahn et al., 2010]. Thus, knowledge of wind speed and direction assists in estimating the average background wind-induced marine aerosol loading in the lower part of SA. The above statements are in agreement with our observations of the increase in southeasterly wind speed $(>5.5 \pm 0.6 \mathrm{~m} / \mathrm{s})$ and $\alpha$ values in both VIS and NIR (see Figures $4 \mathrm{a}$ and $4 \mathrm{~b}$ ), thereby confirming that the lower part of the SA is loaded by windinduced supermicron (marine) aerosols. It is also confirmed by earlier research done over the west coast of SA $\left(30.5^{\circ} \mathrm{S}\right.$; $18^{\circ} \mathrm{E}$ ) by Piketh et al. [1999] who mentioned that, during summer, marine aerosols contribute $\sim 51 \%$ of total aerosol loading. Furthermore, this result along with the Mie scattering theory supports the observation of bright sunrises and sunsets during the above time period in the region.
[20] During the early winter period, the AOD further declines $(12 \%)$ in comparison with summer AOD. This may be due to the decline of wave-generated supermicron maritime aerosols (wind speed $<4.2 \pm 0.5 \mathrm{~m} / \mathrm{s}$ ). Further, during this period, the $\alpha^{\prime}$ varies from 0.24 to 0.62 and the Angstrom exponent values vary from 0.86 to 1.26 and from 0.65 to 1.07 in the VIS and NIR bands, respectively (see Figure 4b). The above values confirm that the coarse-mode aerosol contribution is diminishing with respect to accumulation-mode aerosols. This is mainly attributed to the decline in windinduced, marine, coarse-mode aerosols and an increase in $\mathrm{RH}$, which favors the growth of fine-mode particles into accumulation-mode particles through intercoagulation and humidification processes. The humidification growth of finemode particles may further indicate that a fraction of the wave-generated submicron organic marine aerosols (especially secondary aerosols, which are the outcome of gas-toparticle conversion processes) have a polar functional group in their nature [Hanel, 1976; Horvath, 1996; Cavalli et al., 2004].

[21] The mean AOD and Angstrom exponent values in the VIS and NIR bands for winter (May-July) varies from 0.082 to $0.096,1.07$ to 1.42 , and 0.91 to 1.27 , respectively (see Figures $4 \mathrm{a}$ and $4 \mathrm{~b}$ ). These values, together with the $\alpha^{\prime}$ (see Figure $4 \mathrm{~b}$ ), indicate that the lower part of SA is dominated by a mixture of accumulation-mode and coarse-mode aerosols during winter. Relatively, the accumulation mode is dominant in the aerosol size distribution. This part of SA, having a Mediterranean climate, gets most of its rain during winter (May-July; see Figure 3). Compared to summer and early winter, the winter AOD and wind speed are further decreased by $\sim 27 \%$ and $\sim 35 \%$, respectively (see Figure 4 a). The decline 

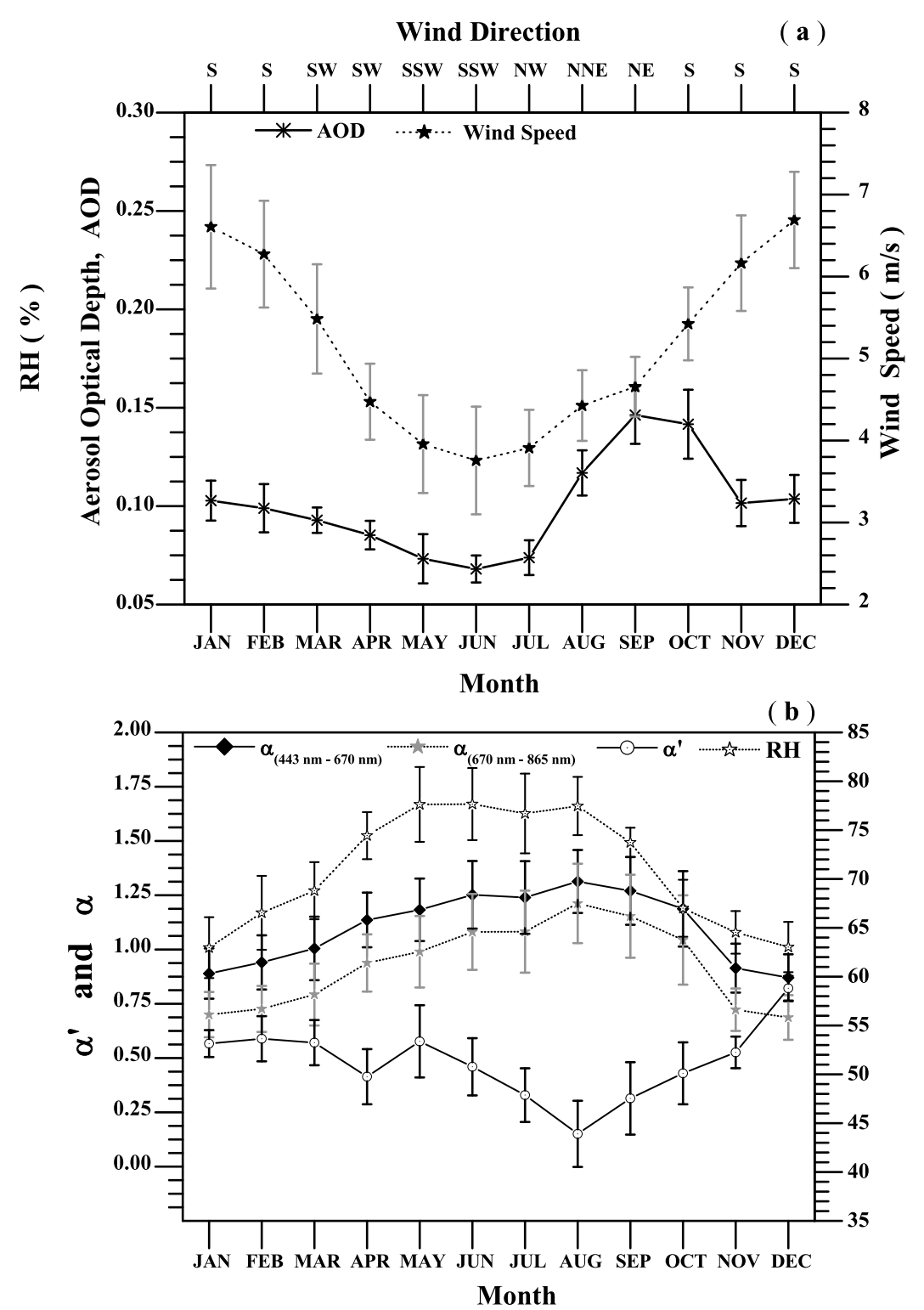

Figure 4. Monthly mean variation (a) of averaged aerosol optical depth (AOD), wind speed, and wind direction (S, southerly; SW, southwesterly; SSW, south-southwesterly; NW, northwesterly; NNE, northnortheasterly; NE, northeasterly) and (b) of Angstrom exponent in both visible and NIR regions, its spectral curvature, and relative humidity (RH) for Lower part, South Africa.

of AOD may be due to the removal of aerosols by various wet deposition processes and less wind-induced marine aerosol load. The dominance of accumulation-mode aerosols during winter can be explained by the fact that during the previous season (summer and early winter period), the atmosphere of this area is more loaded by medium and high wave-generated marine (supermicron and submicron modes) aerosols. Wavegenerated inorganic fresh sea-salt spray and polar functional groups of organic particles are hygroscopic in nature. The aging process in marine aerosols results in more hygroscopic aerosols. For instance, when sulfur dioxide $\left(\mathrm{SO}_{2}\right)$ condenses into the sea-salt aerosol surface, the aerosols transform into sulfate [Sievering et al., 1991; Quinn et al., 2000]. Moreover, due to the more soluble mass presence, marine aerosols act as highly suitable cloud condensation nuclei [Katoshevski et al., 1999; Ross et al., 2003; Matteo et al., 2010]. Thus, this is consistent with our results that, in a situation where the wind speed has been low for an extended period of time, the pool of hygroscopic particles are efficiently removed from the atmosphere by cloud processing and precipitation. In addition to this process, the high RH causes the enlargement of hygroscopic supermicron marine particles. Since the viscous drag is proportional to the particle surface, and the gravitational force scales with the volume, sedimentation also becomes an important removal process during this period.

[22] Early summer months (August-October) indicate that the AOD increases by $\sim 34 \%$ in comparison to the rest of the season. During this period, the Angstrom exponent values in the VIS and NIR bands vary from 1.17 to 1.46 and from 1.03 to 1.40 , respectively (see Figure 4 ). In addition, the observed values of $\alpha$ synchronized with $\alpha^{\prime}$ values (Figure 4b) demonstrate that the optical influence of submicron particles are 
Wind Direction

( a )

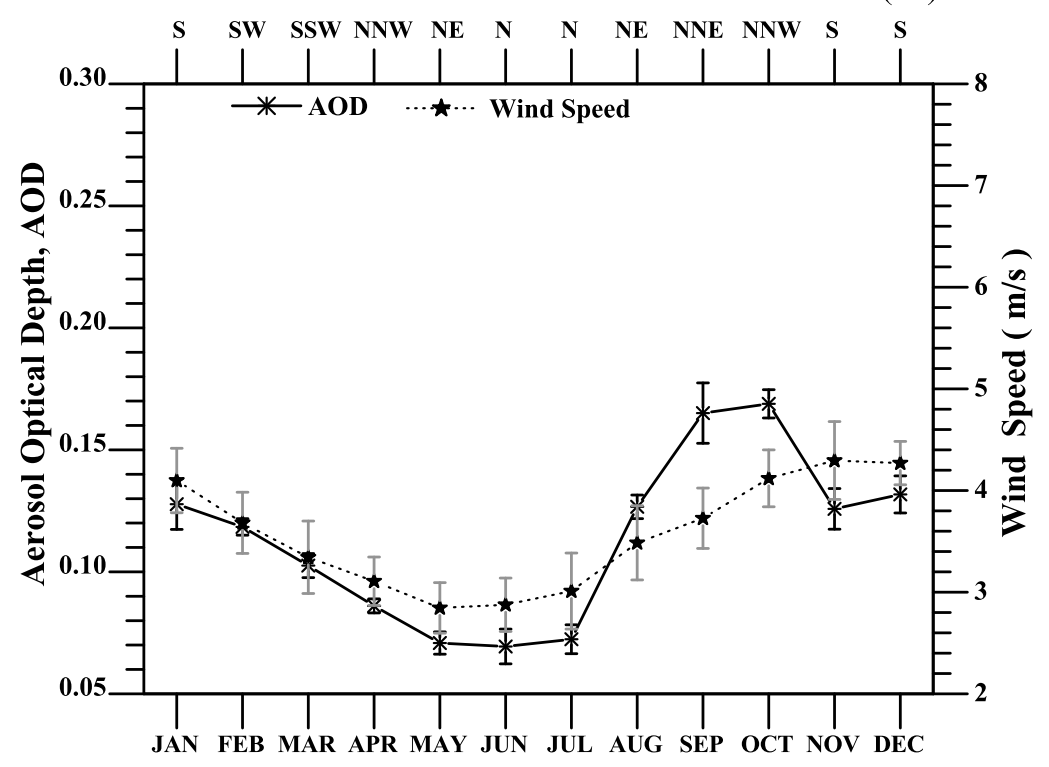

Month

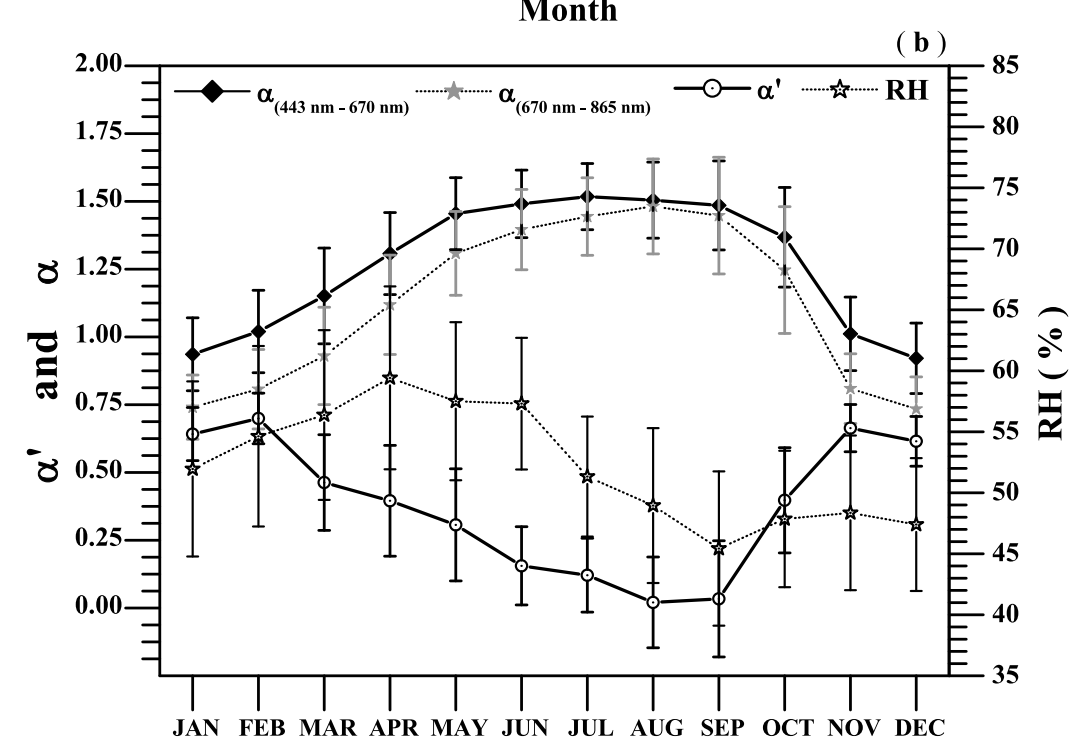

Month

Figure 5. Same as Figure 4 but for central part, South Africa.

stronger than supermicron particles. The dominance of submicron particles can be inferred from the presence of biomass burning and urban aerosols. This is revealed by a significant increase in aerosol absorption optical depth (by about $\sim 71 \%$ in comparison to the rest of the seasons; see Figure $2 b$ ) and increase in $\alpha_{\mathrm{NIR}}$. In addition, during this period we noticed the movement of wind from the intensive biomass-burning areas (i.e., northeastern and central parts of SA and Botswana [Magi et al., 2009]) to the lower part of SA. The above results are found to be in a good agreement with earlier studies based on air mass trajectory analysis [Garstang et al., 1996; Tyson et al., 1996; Tyson and D'Abreton, 1998; Freiman and Piketh, 2003] and onsite measurements at particular sites of SA [Piketh et al., 1999; Formenti et al., 2002; Piketh et al., 2002; Winkler et al., 2008]. However, during the transportation processes, various coagulation and condensation processes cause both chemical and physical changes in the submicron particles.

\subsubsection{Central Part of South Africa}

[23] The monthly mean variation of AOD, wind speed, $\alpha$, $\alpha^{\prime}$ and $\mathrm{RH}$ are given in Figures $5 \mathrm{a}$ and $5 \mathrm{~b}$ (similar to Figures $4 \mathrm{a}$ and $4 \mathrm{~b}$ ) for the central part of the SA. The AOD depicts AO similar to that in the lower part of SA, except that the maximum is observed with a month shift (October). The observed AOD values (during summer and early summer period) are found to increase $(\sim 10 \%-20 \%)$ while the wind speed decreases ( $\sim 29 \%$, throughout the year) in comparison to the lower part of the SA. In relation to the low wind speed, the variation (standard deviation) in AOD is also lower than that of the lower part of the SA (see Figure 5a). During August and March, the difference between observed $\alpha$ values $\left(\alpha_{\text {vis }}\right.$ and $\alpha_{\mathrm{NIR}}$ ) shows 0.02 (minimum) and 0.22 (maximum), 
respectively. This part of the country seems to be drier (low humidity) which is revealed by the observed monthly variation of RH (see Figure 5b). It is evident from Figure $5 b$ that low RH is recorded for early summer and high RH recorded during early winter. More detailed results are discussed in terms of seasonal variations in the following paragraphs.

[24] Figure 5 shows an increase in AOD and $\alpha$ (both VIS and NIR) values while $\alpha^{\prime}$, wind speed, and RH are lower in comparison to the lower parts of SA during summer. The variations of observed AOD, $\alpha_{\mathrm{vis}}, \alpha_{\mathrm{NIR}}$ and $\alpha^{\prime}$ from 0.12 to $0.13,0.79$ to $1.07,0.61$ to 0.93 , and 0.41 to 0.77 respectively, indicate that during summer, the central part of SA is relatively dominated by coarse-mode aerosols. The significant contribution of the coarse-mode particles is probably caused by the transport of air mass by strong southerly (S) and southwesterly (SW) winds from the dry and dusty desert regions of the Northern Cape, Namibia, and Free State (an intensive agricultural places). Moreover, various growth and removal processes of submicron particles, such as scavenging by precipitation, contribute to the relative dominance of coarse-mode particles. The above finding is in relation to the high rainfall during this period (see Figure 3), which favors the growth and removal of submicron aerosols through various wet deposition processes [Ross et al., 2003]. However, the observed AOD, which is higher than in the early winter and winter months, indicates the presence of insoluble particles (inorganic and/or organic mineral) which are continuously being loaded and/or transported by the strong S and SW winds. The sources of such particles are the different urban/ industrial activities and aerosols transported from the arid/ semiarid regions of Northern Cape together with local agricultural activities over Free State. Earlier studies by Piketh et al. [1999, 2002], using size-fractionated aerosol chemical analysis at Ben Macdhui Mountain $\left(\sim 30^{\circ} \mathrm{S}, 28^{\circ} \mathrm{E}\right)$ also revealed that the presence of higher concentration of coarsemode, soil dust particles and agglomerated nitrate and sulfate aerosol on the surface of dust nuclei during summer.

[25] During early winter (March-April), in comparison to summer, the AOD is decreased by $25 \%$, wind speed by $21 \%$, and $\alpha^{\prime}$ by $30 \%$, with an increase in values of $\alpha_{\text {vis }}(1.23 \pm 0.05)$ and $\alpha_{\text {NIR }}(1.02 \pm 0.07)$. These $\alpha$ and $\alpha^{\prime}$ values indicate, in both spectral bands, a relative declination of coarse-mode particles in comparison to the accumulation mode in the aerosol size distribution. Such decreases in coarse-mode particles (also AOD) are caused by weak aerosol generation and dispersion, due to the end of rainy season followed by lower wind speed conditions. During this period, the variation in RH and $\alpha$ values (see Figure 5b) delineate the presence of hygroscopic fine particles which are most likely sulfate and nitrate containing aerosols. The high RH values (i.e., higher moisture) and low wind speed during this period facilitates the humidification growth and different agglomeration processes of fine particles which promotes the dominance of accumulation-mode particles and favors their longer existence. Congruent with the above statement, previous studies have stated that more than $75 \%$ of the plume originate from the industrial regions (Gauteng and Mpumalanga), circulates in the central part for several days, prior to exiting SA [Garstang et al., 1996; Tyson et al., 1996; Tyson and D'Abreton, 1998; Freiman and Piketh, 2003]. Other studies have also observed that this plume consists mainly of submicron particles, such as industrial dust, sulfates, and nitrates
[Formenti et al., 1999; Piketh et al., 1999, 2002; Zunckel et al., 2000].

[26] It is noted from Figure 5a that the AOD shows the lowest values during winter (May-July) while it is highest during early summer (August-October), in comparison to summer and early winter. On the other hand, $\alpha$ and $\alpha^{\prime}$ show almost similar variations (within $\pm 2 \%$ ) between winter and early summer (except October $\alpha^{\prime}$ values range from 0.27 to 0.59). The low AOD during winter is in relation to the observed low and stable wind speed which decreases the number of particles generation and dispersion from local and surrounding arid/semiarid regions. It is evident from the observed $\alpha_{\text {vis }}(1.32-1.65), \alpha_{\text {NIR }}(1.23-1.66)$ and $\alpha^{\prime}$ (negative and near-zero values) during winter and early summer, that this region of SA is dominated by submicron particles. Specifically during August to September, a significant increase in $\tau_{a(558 \mathrm{~nm})}($ by $\sim 75 \%)$ is noticed in comparison to the rest of the months (see Figure 2b), as well, higher values of $\alpha_{\text {NIR }}(>1.4)$ are observed. This indicates that during these months, the area is more loaded by submicron particles originating from biomass burning and various anthropogenic activities. The observed high values of $\tau_{a(558 \mathrm{~nm})}$ and $\alpha_{\mathrm{NIR}}$ are in accordance with Formenti et al. [2003], who noted that the contribution of submicron carbonaceous aerosol is $\sim 80 \%$ relative to the total submicron aerosol during this period. Magi et al. [2009] reported that most of SA's biomassburning activities occur in the eastern-central and northeastern regions. These regions are dominated by sugarcane farming and refineries, where the sugarcane is burnt for preindustrial processing during August to September. In addition, the transport of particles from biomass-burning activities over Botswana and the northern industrial areas of SA also contribute to the load of submicron particles [Tyson and D'Abreton, 1998; Eck et al., 1999, 2001, 2003; Piketh et al., 1999, 2002; Reid et al., 1999; Freiman and Piketh, 2003]. Furthermore, the presence of submicron particles during winter and early summer is favored by the dry and windy atmosphere in this region. The above findings are concurrent with the observed high AOD during early summer. However, relative to the rest of winter and early summer months, during October the declination in $\alpha_{\text {vis }}$ (by $\sim 10 \%$ ), and $\alpha_{\mathrm{NIR}}$ (by $\sim 13 \%$ ) along with the increment in $\alpha^{\prime}$ values were observed. This indicates the dominance of submicron particles in the aerosols size distribution being diminished. This may be due to the reduction of biomass-burning aerosols load, which is revealed by the declination of $\tau_{a(558 \mathrm{~nm})}$ (by $\sim 42 \%$ in comparison to August and September; see Figure $2 b$ ) and the aging processes in submicron particles [Formenti et al., 2003; Ross et al., 2003]. During the Southern African Regional Science Initiative (SAFARI 2000) experiment, Formenti et al. [2003] stated that the range of the aging process in biomassburning-induced submicron particles causes the depletion of their number concentration by $\sim 41 \%$ within a few days, with respect to the young smoke.

\subsubsection{Upper Part of South Africa}

[27] This part of SA is considered to be highly populated, industrialized, and agricultural. As a result, there is a strong desire to study aerosol characteristics in this region. We have plotted the monthly variation of AOD, wind speed, $\alpha, \alpha^{\prime}$, and RH (Figures 6a and 6b). This part of SA also illustrates AO with the maximum AOD during October and the minimum during May (see Figure 6a), which is similar to the rest of SA. 

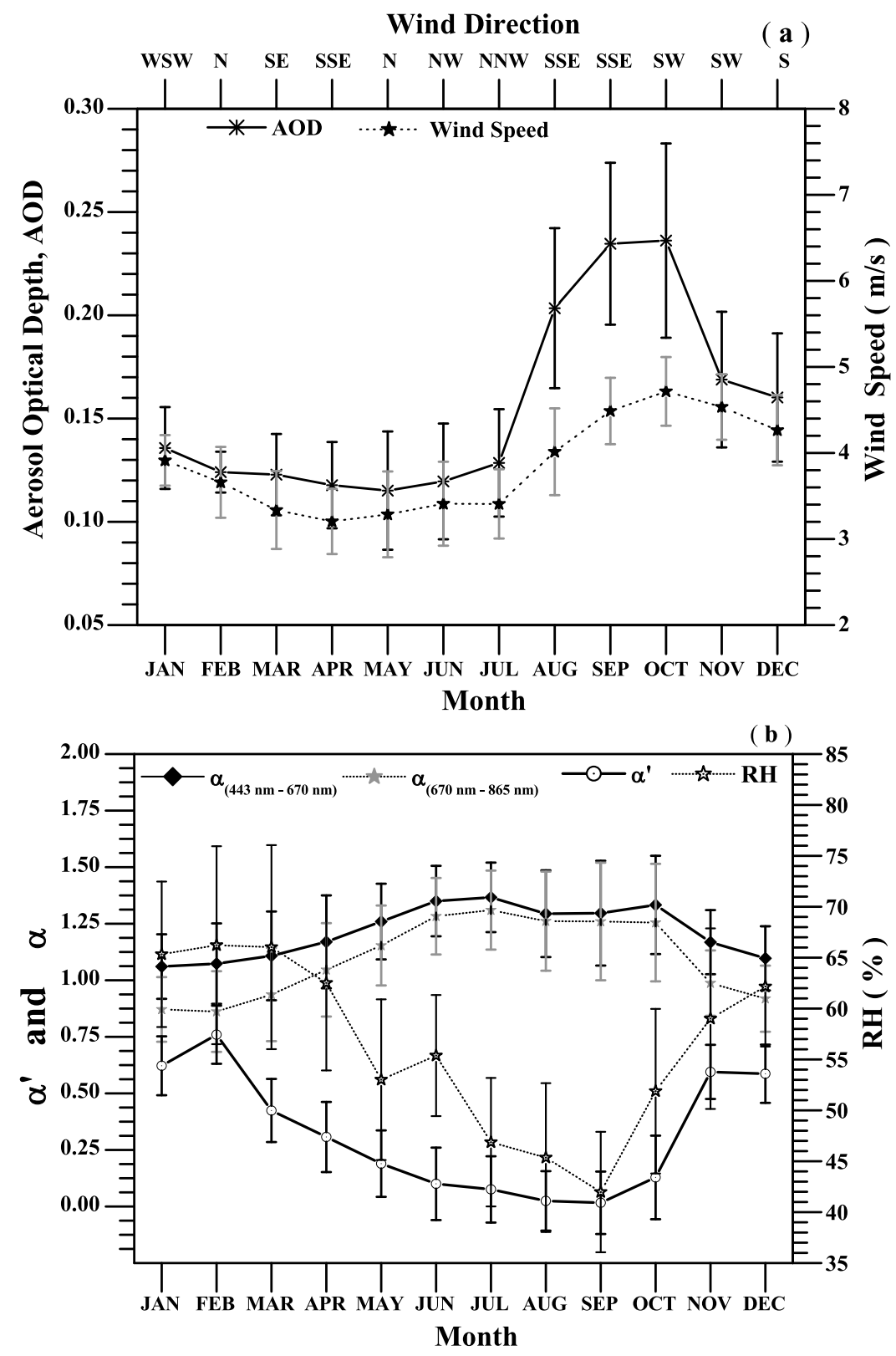

Figure 6. Same as Figure 4 but for upper part, South Africa.

The observed AOD is found to be the highest when compared to the lower $(\sim 34 \%)$ and central $(\sim 27 \%)$ parts of SA. More specifically, the value for this region is $\sim 40 \%$ higher than that in the lower part of SA during winter and early summer, while it exceeds the central part of SA by $\sim 37 \%$ during those periods. In comparison to the central part of SA, the observed wind speed is similar (within the standard deviation) during summer and early winter period, but the upper parts of SA differ by an increase in wind speed of $\sim 14 \%$ during winter and early summer periods. However, the observed wind speed was found to be lower than that in the lower parts of SA, with a maximum difference during summer and early winter. Figure $6 \mathrm{~b}$ shows that throughout the year, $\alpha$ values in both spectral bands are higher than the lower parts of SA while the values are relatively higher than those of the central part of SA during summer, and between the values of the lower and central parts of SA for the remaining seasons. The recorded RH indicates that the upper part of SA is driest with respect to rest of the SA, during winter and early summer. But, during the reciprocal season, the values are higher than those in the central parts of SA.

[28] During summer, AOD values vary from 0.11 to 0.20 , $\alpha_{\text {vis }}$, from 0.89 to $1.23, \alpha_{\mathrm{NIR}}$, from 0.73 to 1.04 and $\alpha^{\prime}$, from 0.21 to 1.06 . This indicates the overall dominance of coarsemode particles in the aerosol size distribution. Wind direction analysis was more complex due to easterly, westerly, northeasterly, and southerly components. The increase in AOD along with wind speed (see Figure 6a) implies that the dominance of coarse-mode aerosols is due to wind-ablated mineral particles, which are the result of local agricultural activities and the air mass transport from or through central parts of SA, Botswana, and Mozambique (arid and semiarid 
regions) [Tyson et al., 1996; Freiman and Piketh, 2003]. The observed RH and $\alpha$ (see Figure 6b, indirectly proportional variation) values indicate that hygroscopic growth of accumulation-mode and/or fine-mode aerosols also contribute to the dominance of coarse-mode particles. Piketh et al. [1999, 2002] also reported that such particles are dominantly originated and sprayed over remote regions of the subcontinent from the industrialized Highveld region $\left(25.2^{\circ} \mathrm{S}\right.$ to $27.2^{\circ} \mathrm{S}$, $27.2^{\circ} \mathrm{E}$ to $29.2^{\circ} \mathrm{E}$ ) of $\mathrm{SA}$, which is located in our upper part. Further, continued energy dispersive analysis indicated that in moist atmosphere those fine particles will rapidly agglomerate on the surface of other particulate and increase their size [Piketh et al., 1999]. In relation to the above findings (the hygroscopic nature of submicron particles); the noticed high rainfall during this period (see Figure 3) causes the degradation of submicron aerosols through various wet deposition processes.

[29] In comparison with summer, during early winter, a decrease in AOD values $(\sim 18 \%), \alpha^{\prime}(\sim 25 \%)$, wind speed $(\sim 20 \%)$, and increases in values for $\alpha_{\mathrm{vis}}(1.17 \pm 0.21)$ and $\alpha_{\text {NIR }}(1.05 \pm 0.21)$ are noted. The decrease in AOD is due to the observed low wind speed which causes less aerosol generation and dispersion. Also, the increase in $\alpha$ and decrease in $\alpha^{\prime}$ values imply an overall dominance of accumulation-mode aerosols. It is due to the decrease in wind-induced, coarse-mode particles and the depletion of various wet deposition processes (due to the end of the rainy season; see Figure 3) [Ross et al., 2003].

[30] Figure 6a shows the lowest AOD $(\sim 0.12)$ values during winter (May-July), when the upper part of SA is characterized by the lowest precipitation, and is driest and with lower wind conditions, relative to the central and lower parts of SA. Thus, the lowest AOD values are attributed to the extended period of lower, stable wind speed patterns which cause weak generation and dispersion of particles. Excluding the Polokwane area $\left(24.3^{\circ} \mathrm{S}\right.$ to $23.2^{\circ} \mathrm{S}, 28.5^{\circ} \mathrm{E}$ to $\left.29.6^{\circ} \mathrm{E}\right)$, the $\alpha$ values computed for VIS and NIR spectral bands during these months vary from 1.19 to 1.53 and from 1.10 to 1.48 , respectively (see Figure 6b). Further, the observed negative and near-zero values of $\alpha^{\prime}$ (from -0.16 to 0.28 ; see Figure $6 \mathrm{~b}$ ) in concert with the above $\alpha$ values, indicate that the area is dominated by a mixture of nucleation and accumulationmode particles during this period. This reveals that the dry and low wind speed conditions are the most advantageous for the long time existence of submicron particles. In addition, in situations where the aerosol absorption optical depth shows very low values $\left(\tau_{a(558 \mathrm{~nm})}<0.004\right)$, the dominance of submicron particles over most areas of the upper part of SA indicates that it is induced by large industrial and urban activities, which are highly abundant in this region.

[31] During the early summer period (August-October), the highest values of AOD ( $0.23 \pm 0.05)$, wind speed ( $4.45 \pm$ $0.43 \mathrm{~m} / \mathrm{s})$ and a significant increase in $\tau_{a(558 \mathrm{~nm})}(\sim 63 \%)$ are observed, in comparison to the rest of the seasons (see Figures $2 \mathrm{~b}$ and $6 \mathrm{a}$ ). In addition, during this period, excluding the Polokwane area, the $\alpha_{\text {vis }}$ varies from 1.18 to $1.62, \alpha_{\mathrm{NIR}}$ from 1.17 to 1.55 , and $\alpha^{\prime}$ from -0.26 to 0.24 , indicating the increase in the submicron particle load (in comparison to winter). These values of $\alpha, \alpha^{\prime}$ and $\tau_{a(558 \mathrm{~nm})}$ associated with the observed wind speed and directions, illustrate that the elevated loads of submicron particles might be induced by local and/or transported biomass-burning aerosols (from the northeastern and central parts of SA and neighboring countries [Magi et al., 2009]) together with the contributions from the abundant industrial/urban activities within this area [Tyson and D'Abreton, 1998; Eck et al., 1999, 2001, 2003; Reid et al., 1999; Campbell et al., 2003; Formenti et al., 2003; Ross et al., 2003; Queface et al., 2011]. In general, from winter to early summer (dry seasons), the $\alpha$ and $\alpha^{\prime}$ values show a dominant effect of fine-mode particles around Gauteng and Mpumalanga. These areas are highly populated and industrialized, which confirms the contribution and effect of anthropogenic activities in air pollution. However, during these dry seasons, around Polokwane (specifically, $24.3^{\circ} \mathrm{S}$ to $23.2^{\circ} \mathrm{S}, 28.5^{\circ} \mathrm{E}$ to $29.6^{\circ} \mathrm{E}$ ), the values of $\alpha_{\text {vis }}$ from 0.86 to $1.10, \alpha_{\mathrm{NIR}}$ from 0.77 to 1.00 , and $\alpha^{\prime}$ from 0.31 to 0.76 , are noted. The noted $\alpha$ and $\alpha^{\prime}$ values indicate that there is a significant coarse-mode aerosol contribution in the aerosol size distribution around this part of SA. This is related to the intensive local agricultural activities and land cover changes around the area, including the influence of strong windablated particles that originated from arid/semiarid regions of the central parts of SA, Namibia, and Botswana (evident from the observed wind speed and directions). In addition, during this period, the windy and drier meteorological conditions favor the load and dispersion of wind-ablated mineral particles and inhibit the hygroscopic growth of submicron aerosols, respectively. In addition to the above major sources, a further source of supermicron particles in Limpopo, might be due to an aged, polluted plume which is transported from intensive biomass-burning activities in the tropical region of southern Africa [Magi et al., 2009] and from mining industries of Zambian copper belt [Freiman and Piketh, 2003; Zunckel et al., 2000]. Generally, throughout the year, the exaggerated differences in AOD values (in comparison with the central $(\sim 27 \%)$ and the lower $(\sim 35 \%)$; see Figure $2 \mathrm{a})$ are noted in the upper part of SA. As well as, excluding the extended biomass burning seasons in southern Africa (JuneOctober), the absorbing aerosol load in this area is higher than the rest of SA (in terms of $\tau_{a(558 \mathrm{~nm})}$ by $\sim 31 \%$; see Figure $2 \mathrm{~b}$ ). These clearly indicate the existence of various local sources within this part of the country.

\section{Summary and Concluding Remarks}

[32] Here, for the first time, a thorough study of the spatial and seasonal aerosol climatological characteristics over SA, based on 10 years of MISR data is presented. The aerosol climatological characteristics were based on aerosol extinction $\left(\tau_{\text {ext }}\right)$, absorption $\left(\tau_{a}\right)$ optical depths at $558 \mathrm{~nm}$, and an extracted Angstrom exponent $(\alpha)$ in two different bands (VIS and NIR) and its spectral curvature $\left(\alpha^{\prime}\right)$. The aerosol spatial variation was studied by classifying SA into lower, central, and upper parts. The seasonal or climatological variations are described in terms of four seasons: summer (NovemberFebruary), early winter (March-April), winter (May-July), and early summer (August-October). Background weather parameters, such as RH, rainfall, and wind speed are used to interpret the aerosol climatological characteristics. The major findings from this study are as follows:

[33] 1. In general, the overall aerosol extinction optical depth values at $558 \mathrm{~nm}$ illustrate annual trends with a maximum during early summer and minimum during winter. The observed maximum during spring corresponds with 
biomass-burning activities in southern Africa. The lower, central, and upper parts of SA demonstrated lower, medium, and higher aerosol load levels, respectively. On the basis of the Angstrom exponent $(\alpha)$ and its spectral curvature $\left(\alpha^{\prime}\right)$, the aerosol size (fine, accumulation/mixture, and coarse modes) distributions are found to be significantly different due to various prevailing source mechanisms.

[34] 2. The lower part of SA is dominated by coarse-mode aerosols during summer. Thereafter, the coarse-mode aerosols load recedes. There is an increase in aerosol load $(\sim 35 \%)$ during early summer in comparison with the remaining seasons. The size distribution is found to be dominated by submicron particles due to massive biomass burning and industrial/urban aerosols load (also evident from the aerosol absorption optical depth). In this part of SA, local anthropogenic aerosol sources are limited. However, the aerosol load might be due to air mass transfer from the surrounding marine environment (during summer) and polluted air mass transport from other regions of SA or from neighboring countries (for the remaining seasons) is the prevailing source of aerosols in this part of SA.

[35] 3. The central part of SA had a $10 \%-20 \%$ increase in aerosol load in comparison with the lower part. During summer, the area shows a dominance of coarse-mode particles in the aerosol size distribution in comparison with the other seasons. These are typically induced by the dry and dusty desert regions of Northern Cape and Namibia. Specifically, during spring a decrease in coarse-mode particles is evident due to the presence of submicron particles which are generated by the load of biomass burning aerosols (also evident from aerosol absorption optical depth) and various anthropogenic activities in and around the area.

[36] 4. The upper part of SA is found to be rich in aerosol reservoirs and the aerosol loading (based on AOD) is $\sim 34 \%$ higher than that in the lower part and $\sim 27 \%$ higher than that in the central part of SA. During different seasons, the aerosol size distribution is dominated by various particle modes. During summer and early winter, the area is dominated by a mixture of coarse-mode and accumulation-mode particles. During winter and early summer, it is dominated by submicron particles. Overall, this part of SA shows a high variability with respect to $\alpha$, indicating numerous aerosol sources in the region. The source and generating mechanisms are found to differ with the observed aerosol mode. In general, the prevailing sources of coarse particles around the area are local agricultural activities and air mass transport from arid/ semiarid regions of the central parts of SA, Botswana, and Namibia; together with various aging processes of submicron aerosols. The prevailing sources of submicron particles are industrial and urban activities (including mines and biomass burning).

[37] 5. It is found that SA experiences drastic turbidity due to high levels of biomass-burning aerosol loadings during August to October, relative to other months.

[38] 6. On the basis of simultaneous observations of monthly average aerosol optical and local meteorological parameter variations, we have noted that the rainy season, followed by a period of lower wind conditions, is the most unfavorable for aerosol generation and dispersion. In contrast, dry and high wind conditions are the most favorable for submicron aerosol loading, dispersion, and long-term existence.
[39] Acknowledgments. The authors are thankful to NASA Langley Atmospheric Science Data Center for providing the MISR satellite data. We are also thankful to the South Africa Weather Service for providing meteorological data. We also thank for all the anonymous reviewers for constructive comments which has improved the quality of the manuscript. The author M. Tesfaye is financially supported by the African Laser Centre, South Africa. Authors thank Ameeth Sharma for proof reading and language correction in the manuscript.

\section{References}

Abdou, W. A., et al. (2005), Comparison of coincident Multiangle Imaging Spectroradiometer and Moderate Resolution Imaging Spectroradiometer aerosol optical depths over land and ocean scenes containing Aerosol Robotic Network sites, J. Geophys. Res., 110, D10S07, doi:10.1029/ 2004JD004693.

Adeyewa, Z. D., and E. E. Balogun (2003), Wavelength dependence of aerosol optical depth and the fit of the Angstrom law, Theor. Appl. Climatol., 74, 105-122, doi:10.1007/s00704-002-0707-3.

Angstrom, A. K. (1929), On the atmospheric transmission of Sun radiation and on dust in the air, Geogr. Ann., 12, 130-159.

Basart, S., C. Perez, E. Cuevas, J. M. Baldasano, and G. P. Gobbi (2009), Aerosol characterization in Northern Africa, Northeastern Atlantic, Mediterranean Basin and Middle East from direct-Sun AERONET observations, Atmos. Chem. Phys., 9, 8265-8282, doi:10.5194/acp-9-8265-2009.

Cachorro, V. E., R. Vergaz, and A. M. de Frutos (2001), A quantitative comparison of $\alpha$ - $\AA$ turbidity parameter retrieved in different spectral ranges based on spectroradiometer solar radiation measurements, Atmos. Environ., 35, 5117-5124, doi:10.1016/S1352-2310(01)00321-1.

Campbell, J. R., E. J. Welton, J. D. Spinhirne, Q. Ji, S.-C. Tsay, S. J. Piketh, M. Barenbrug, and B. N. Holben (2003), Micropulse lidar observations of tropospheric aerosols over northeastern South Africa during the ARREX and SAFARI 2000 dry season experiments, J. Geophys. Res., 108(D13), 8497, doi:10.1029/2002JD002563.

Cavalli, F., et al. (2004), Advances in characterization of size-resolved organic matter in marine aerosol over the North Atlantic, J. Geophys. Res., 109, D24215, doi:10.1029/2004JD005137.

Charlson, R. J., S. E. Schwartz, J. M. Hales, R. D. Cess, R. D. Coakley, J. E. Hansen, and D. J. Hofmann (1992), Climate forcing by anthropogenic aerosols, Science, 255, 423-430, doi:10.1126/science.255.5043.423.

Christopher, S. A., and J. Wang (2004), Intercomparison between multiangle imaging spectroradiometer (MISR) and sunphotometer aerosol optical thickness in dust source regions over China: Implications for satellite aerosol retrievals and radiative forcing calculations, Tellus, Ser. B, 56(5), 451-456, doi:10.1111/j.1600-0889.2004.00120.x.

Christopher, S. A., and J. Zhang (2002), Shortwave aerosol radiative forcing from MODIS and CERES observations over the oceans, Geophys. Res. Lett., 29(18), 1859, doi:10.1029/2002GL014803.

Dey, S., and L. Di Girolamo (2010), A climatology of aerosol optical and microphysical properties over the Indian subcontinent from 9 years (2000-2008) of Multiangle Imaging Spectroradiometer (MISR) data, J. Geophys. Res., 115, D15204, doi:10.1029/2009JD013395.

Diner, D. J., et al. (1998), Multi-angle Imaging SpectroRadiometer (MISR) instrument description and experiment overview, IEEE Trans. Geosci. Remote Sens., 36, 1072-1087, doi:10.1109/36.700992.

Diner, D. J., et al. (1999), New directions in Earth observing: Scientific applications of multi-angle remote sensing, Bull. Am. Meteorol. Soc., 80, 2209-2228, doi:10.1175/1520-0477(1999)080<2209:NDIEOS $>2.0$. $\mathrm{CO} ; 2$.

Diner, D. J., et al. (2001), MISR aerosol optical depth retrievals over southern Africa during the SAFARI-2000 dry season campaign, Geophys. Res. Lett., 28(16), 3127-3130, doi:10.1029/2001GL013188.

Diner, D. J., et al. (2005), The value of multiangle measurements for retrieving structurally and radiatively consistent properties of clouds, aerosols, and surfaces, Remote Sens. Environ., 97, 495-518, doi:10.1016/j. rse.2005.06.006.

Eck, T. F., et al. (1999), Wavelength dependence of the optical depth of biomass burning, urban, and desert dust aerosols, J. Geophys. Res., 104, 31,333-31,349, doi:10.1029/1999JD900923.

Eck, T. F., et al. (2001), Characterization of the optical properties of biomass burning aerosols in Zambia during the 1997 ZIBBEE field campaign, J. Geophys. Res., 106, 3425-3448, doi:10.1029/2000JD900555.

Eck, T. F., et al. (2003), Variability of biomass burning aerosol optical characteristics in southern Africa during the SAFARI 2000 dry season campaign and a comparison of single scattering albedo estimates from radiometric measurements, J. Geophys. Res., 108(D13), 8477, doi:10.1029/ 2002JD002321.

Formenti, P., S. J. Piketh, and H. J. Annegarn (1999), Detection of non-sea salt sulphate aerosol at a remote coastal site in South Africa: A PIXE 
study, Nucl. Instrum. Methods Phys. Res., Sect. B, 150, 332-338, doi:10.1016/S0168-583X(98)01041-6.

Formenti, P., H. Winkler, P. Fourie, S. Piketh, B. Makgopa, G. Helas, and M. O. Andreae (2002), Aerosol optical depth over a remote semi-arid region of South Africa from spectral measurements of the daytime solar extinction and the nighttime stellar extinction, Atmos. Res., 62, 11-32, doi:10.1016/S0169-8095(02)00021-2.

Formenti, P., W. Elbert, W. Maenhaut, J. Haywood, S. Osborne, and M. O. Andreae (2003), Inorganic and carbonaceous aerosols during the Southern African Regional Science Initiative (SAFARI 2000) experiment: Chemical characteristics, physical properties, and emission data for smoke from African biomass burning, J. Geophys. Res., 108(D13), 8488, doi:10.1029/2002JD002408.

Freiman, M. T., and S. J. Piketh (2003), Air transport into and out of the industrial Highveld region of South Africa, J. Appl. Meteorol., 42 , 994-1002, doi:10.1175/1520-0450(2003)042<0994:ATIAOO>2.0.CO;2.

Garstang, M., P. D. Tyson, R. Swap, M. Edwards, P. Kållberg, and J. A. Lindesay (1996), Horizontal and vertical transport of air over southern Africa, J. Geophys. Res., 101, 23,721-23,736, doi:10.1029/95JD00844.

Gobbi, G. P., Y. J. Kaufman, I. Koren, and T. F. Eck (2007), Classification of aerosol properties derived from AERONET direct Sun data, Atmos. Chem. Phys., 7, 453-458, doi:10.5194/acp-7-453-2007.

Gong, S., L. Barrie, and J. P. Blanchet (1997), Modeling sea-salt aerosols in the atmosphere 1. Model development, J. Geophys. Res., 102, 3805-3818, doi:10.1029/96JD02953.

Hanel, G. (1976), The properties of atmospheric aerosol particles as functions of relative humidity at thermodynamic equilibrium with surrounding moist air, Adv. Geophys., 19, 73-188, doi:10.1016/S0065-2687(08) 60142-9.

Hansen, J., M. Sato, and R. Ruedy (1997), Radiative forcing and climate response, J. Geophys. Res., 102, 6831-6864, doi:10.1029/96JD03436.

Haywood, J., and O. Boucher (2000), Estimates of the direct and indirect radiative forcing due to tropospheric aerosols: A review, Rev. Geophys., 38, 513-543, doi:10.1029/1999RG000078.

Holben, B. N., E. Vermote, Y. J. Kaufman, D. Tanré, and V. Kalb (1992), Aerosol retrieval overland from AVHRR data-application for atmospheric correction, IEEE Trans. Geosci. Remote Sens., 30, 212-222, doi: $10.1109 / 36.134072$

Holben, B. N., et al. (2001), An emerging ground-based aerosol climatology: Aerosol optical depth from AERONET, J. Geophys. Res., 106 12,067-12,097, doi:10.1029/2001JD900014.

Hoppel, W., J. Fitzgerald, G. Frick, R. Larson, and E. Mack (1990), Aerosol size distributions and optical properties found in the marine boundary layer over the Atlantic Ocean, J. Geophys. Res., 95, 3659-3686, doi:10.1029/JD095iD04p03659.

Horvath, H. (1996), Spectral extinction coefficients of rural aerosol in southern Italy: A case study of cause and effect of variability of atmospheric aerosol, J. Aerosol Sci., 27, 437-453, doi:10.1016/0021-8502 (95)00544-7.

Ichoku, C., L. A. Remer, Y. J. Kaufman, R. Levy, D. A. Chu, D. Tanré, and B. N. Holben (2003), MODIS observation of aerosols and estimation of aerosol radiative forcing over southern Africa during SAFARI 2000, J. Geophys. Res., 108(D13), 8499, doi:10.1029/2002JD002366.

Ignatov, A., and L. Stowe (2002), Aerosol retrievals from individua AVHRR channels, part I: Retrieval algorithm and transition from Dave to 6S radiative transfer model, J. Atmos. Sci., 59, 313-334, doi:10.1175/1520-0469(2002)059<0313:ARFIAC $>2.0 . \mathrm{CO} ; 2$

Intergovernmental Panel on Climate Change (2007), Climate Change 2007: Synthesis Report, edited by The Core Writing Team, R. K. Pachauri, and A. Reisinger, Geneva, Switzerland. [Avaliable at http://www.ipcc.ch/pdf/ assessment-report/ar4/syr/ar4_syr.pdf]

James, W., et al. (2000), Association between air pollution and lung function growth in southern California children, Am. J. Respir. Crit. Care Med., 162, 1383-1390.

Jayaraman, A. (2001), Aerosol radiation cloud interactions over the tropical Indian Ocean prior to the onset of the summer monsoon, Curr. Sci., 81, $1437-1445$

Jiang, X., Y. Liu, B. Yu, and M. Jiang (2007), Comparison of MISR aerosol optical thickness with AERONET measurements in Beijing metropolitan area, Remote Sens. Environ., 107, 45-53, doi:10.1016/j. rse.2006.06.022

Kahn, R., P. Banerjee, and D. McDonald (2001), Sensitivity of multiangle imaging to natural mixtures of aerosols over ocean, J. Geophys. Res., 106, 18,219-18,238, doi:10.1029/2000JD900497.

Kahn, R. A., B. J. Gaitley, J. V. Martonchik, D. J. Diner, K. A. Crean, and B. Holben (2005), Multiangle Imaging Spectroradiometer (MISR) globa aerosol optical depth validation based on 2 years of coincident Aerosol Robotic Network (AERONET) observations, J. Geophys. Res., 110, D10S04, doi:10.1029/2004JD004706.
Kahn, R. A., M. J. Garay, D. L. Nelson, K. K. Yau, M. A. Bull, B. J. Gaitley, J. V. Martonchik, and R. C. Levy (2007), Satellite-derived aerosol optical depth over dark water from MISR and MODIS: Comparisons with AERONET and implications for climatological studies, J. Geophys. Res., 112, D18205, doi:10.1029/2006JD008175.

Kahn, R. A., D. L. Nelson, M. J. Garay, R. C. Levy, M. A. Bull, D. J. Diner, J. V. Martonchik, S. R. Paradise, E. G. Hansen, and L. A. Remer (2009), MISR aerosol product attributes and statistical comparisons with MODIS, IEEE Trans. Geosci. Remote Sens., 47, 4095-4114, doi:10.1109/TGRS.2009.2023115.

Kahn, R. A., B. J. Gaitley, M. J. Garay, D. J. Diner, T. F. Eck, A. Smirnov, and B. N. Holben (2010), Multiangle Imaging SpectroRadiometer globa aerosol product assessment by comparison with the Aerosol Robotic Network, J. Geophys. Res., 115, D23209, doi:10.1029/2010JD014601.

Kalashnikova, O. V., and R. Kahn (2006), Ability of multiangle remote sensing observations to identify and distinguish mineral dust types: 2. Sensitivity over dark water, J. Geophys. Res., 111, D11207, doi:10.1029/2005JD006756.

Kalashnikova, O. V., and R. A. Kahn (2008), Mineral dust plume evolution over the Atlantic from MISR and MODIS aerosol retrievals, J. Geophys. Res., 113, D24204, doi:10.1029/2008JD010083.

Kalashnikova, O. V., R. Kahn, I. N. Sokolik, and W.-H. Li (2005), The ability of multi-angle remote sensing observations to identify and distinguish mineral dust types: Optical models and retrievals of optically thick plumes, J. Geophys. Res., 110, D18S14, doi:10.1029/2004JD004550.

Kaskaoutis, D. G., and H. D. Kambezidis (2006), Checking the validity of the Angstrom's formula with spectral data of direct beam irradiance obtained in Athens, Greece, Atmos. Res., 79, 67-87, doi:10.1016/j. atmosres.2005.05.001.

Katoshevski, D., A. Nenes, and J. H. Seinfeld (1999), A study of processes that govern the maintenance of aerosols in the marine boundary layer, J. Aerosol Sci., 30, 503-532, doi:10.1016/S0021-8502(98)00740-X.

Kaufman, Y. J. (1993), Aerosol optical thickness and atmospheric path radiance, J. Geophys. Res., 98, 2677-2692, doi:10.1029/92JD02427.

Kaufman, Y. J., A. Setzer, D. Ward, D. Tanre, B. N. Holben, P. Menzel, M. C. Pereira, and R. Rasmussen (1992), Biomass burning airborne and space borne experiment in the Amazonas (BASE-A), J. Geophys. Res., 97, 14,581-14,599, doi:10.1029/92JD00275.

Kaufman, Y. J., D. Tanre, L. A. Remer, E. F. Vermote, A. Chu, and B. N. Holben (1997), Operational remote sensing of tropospheric aerosol over land from EOS moderate resolution imaging spectroradiometer, J. Geophys. Res., 102, 17,051-17,067, doi:10.1029/96JD03988.

Kaufman, Y., D. Tanre, and O. Boucher (2002), A satellite view of aerosols in the climate system, Nature, 419, 215-223, doi:10.1038/nature01091.

King, M. D., and D. M. Byrne (1976), A method for inferring total ozone content from spectral variation of total optical depth obtained with a solar radiometer, J. Atmos. Sci., 33, 2242-2251, doi:10.1175/1520-0469(1976) 033<2242:AMFITO>2.0.CO;2.

King, M., D. Byrne, B. Herman, and J. Reagan (1978), Aerosol size distributions obtained by inversion of spectral optical depth measurements, J. Atmos. Sci., 35, 2153-2167, doi:10.1175/1520-0469(1978)035<2153 ASDOBI $>2.0 . \mathrm{CO} ; 2$

King, M. D., Y. J. Kaufman, D. Tanre, and T. Nakajima (1999), Remote sensing of tropospheric aerosols from space: Past, present, and future, Bull. Am. Meteorol. Soc., 80, 2229-2259, doi:10.1175/1520-0477 (1999) 080<2229:RSOTAF $>2.0 . \mathrm{CO} ; 2$

Latham, J., and M. Smith (1990), Effect on global warming of winddependent aerosol generation at the ocean surface, Nature, 347, 372-373, doi:10.1038/347372a0.

Lehahn, Y., I. Koren, E. Boss, Y. Ben-Ami, and O. Altaratz (2010), Estimating the maritime component of aerosol optical depth and its dependency on surface wind speed using satellite data, Atmos. Chem. Phys., 10, 6711-6720, doi:10.5194/acp-10-6711-2010.

Levy, R. C., et al. (2003), Evaluation of the Moderate-Resolution Imaging Spectroradiometer (MODIS) retrievals of dust aerosol over the ocean during PRIDE, J. Geophys. Res., 108(D19), 8594, doi:10.1029/ 2002JD002460.

Levy, R. C., G. G. Leptoukh, R. Kahn, V. Zubko, A. Gopalan, and L. A. Remer (2009), A critical look at deriving monthly aerosol optical depth from satellite data, IEEE Trans. Geosci. Remote Sens., 47, 2942-2956, doi:10.1109/TGRS.2009.2013842.

Liu, L. (2005), Improving GCM Aerosol Climatology using satellite and ground based measurements, paper presented at 15 th ARM Science Team Meeting, Atmos. Radiat. Meas. (ARM) Program, Daytona Beach, Fla., 14-18 March.

Liu, Y., J. A. Sarnat, B. A. Coull, P. Koutrakis, and D. J. Jacob (2004), Validation of Multiangle Imaging Spectroradiometer (MISR) aerosol optical thickness measurements using Aerosol Robotic Network (AERONET) 
observations over the contiguous United States, J. Geophys. Res., 109, D06205, doi:10.1029/2003JD003981.

Magi, B. I., P. Ginoux, Y. Ming, and V. Ramaswamy (2009), Evaluation of tropical and extratropical Southern Hemisphere African aerosol properties simulated by a climate model, J. Geophys. Res., 114, D14204, doi:10.1029/2008JD011128.

Mallet, M., J. C. Roger, S. Despiau, O. Dubovik, and J. P. Putaud (2003), Microphysical and optical properties of aerosol particles in urban zone during ESCOMPTE, Atmos. Res., 69, 73-97, doi:10.1016/j.atmosres. 2003.07.001

Martonchik, J. V., et al. (1998), Techniques for the retrieval of aerosol properties over land and ocean using multi-angle imaging, IEEE Trans. Geosci. Remote Sens., 36(4), 1212-1227, doi:10.1109/36.701027.

Martonchik, J. V., D. J. Diner, K. A. Crean, and M. A. Bull (2002), Regional aerosol retrieval results from MISR, IEEE Trans. Geosci. Remote Sens., 40(7), 1520-1531, doi:10.1109/TGRS.2002.801142.

Martonchik, J. V., D. J. Diner, R. Kahn, B. Gaitley, and B. N. Holben (2004), Comparison of MISR and AERONET aerosol optical depths over desert sites, Geophys. Res. Lett., 31, L16102, doi:10.1029/ 2004GL019807.

Masmoudi, M., M. Chaabane, D. Tanre, P. Gouloup, L. Blarel, and F. Elleuch (2003), Spatial and temporal variability of aerosol: Size distribution and optical properties, Atmos. Res., 66, 1-19, doi:10.1016/S01698095(02)00174-6.

Matteo, R., et al. (2010), Primary and secondary organic marine aerosol and oceanic biological activity: Recent results and new perspectives for future studies, Adv. Meteorol., 310682, doi:10.1155/2010/310682.

de Meij, A. and J. Lelieveld (2011), Evaluating aerosol optical properties observed by ground-based and satellite remote sensing over the Mediterranean and the Middle East in 2006, Atmos. Res., 99, 415-433, doi:10.1016/j.atmosres.2010.11.005

Muller, J., A. Mandanayake, C. Moroney, R. Davies, D. J. Diner, and S. Paradise (2002), MISR stereoscopic image matchers: Techniques and results, IEEE Trans. Geosci. Remote Sens., 40(7), 1547-1559, doi:10.1109/TGRS.2002.801160.

Nakajima, T., T. Takamura, and M. Yamano (1986), Consistency of aerosol size distributions inferred from measurements of solar radiation and aerosols, J. Meteorol. Soc. Jpn., 64, 765-776.

O'Dowd, C., and G. de Leeuw (2007), Marine aerosol production: A review of the current knowledge, Philos. Trans. R. Soc. A, 365 1753-1774, doi:10.1098/rsta.2007.2043.

O'Dowd, C., and M. Smith (1993), Physicochemical properties of aerosols over the northeast Atlantic: Evidence for wind-speed-related submicron sea-salt aerosol production, J. Geophys. Res., 98, 1137-1149, doi:10.1029/92JD02302.

O'Dowd, C., M. Smith, I. Consterdine, and J. Lowe (1997), Marine aerosol, sea-salt, and the marine sulphur cycle: A short review, Atmos. Environ., 31, 73-80, doi:10.1016/S1352-2310(96)00106-9.

O'Neill, N. T., O. Dubovik, and T. F. Eck (2001a), A modified Angstrom coefficient for the characterization of sub-micron aerosols, Appl. Opt., 40, 2368-2374

O'Neill, N. T., T. F. Eck, B. N. Holben, A. Smirnov, and O. Dubovick (2001b), Bimodal size distribution influences on the variation of Angstrom derivatives in spectral and optical depth space, J. Geophys. Res., 106, 9787-9806, doi:10.1029/2000JD900245.

O'Neill, N. T., T. F. Eck, B. N. Holben, A. Smirnov, A. Royer, and Z. Li (2002), Optical properties of boreal forest fire smoke derived from Sun photometry, J. Geophys. Res., 107(D11), 4125, doi:10.1029/ 2001JD000877.

O'Neill, N. T. T. F. Eck, A. Smirnoy, B. N. Holben, and S. Thulasiraman (2003), Spectral discrimination of coarse and fine mode optical depth, J. Geophys. Res., 108(D17), 4559, doi:10.1029/2002JD002975.

Piketh, S. J., H. J. Annegarn, and P. D. Tyson (1999), Lower tropospheric aerosol loadings over South Africa: The relative contribution of aeolian dust, industrial emissions, and biomass burning, J. Geophys. Res., 104, 1597-1607, doi:10.1029/1998JD100014.
Piketh, S. J., R. J. Swap, W. Maenhaut, H. J. Annegarn, and P. Forment (2002), Chemical evidence of long-range atmospheric transport over southern Africa, J. Geophys. Res., 107(D24), 4817, doi:10.1029/ 2002JD002056.

Prasad, A. K., and R. P. Singh (2007), Comparison of MISR-MODIS aerosol optical depth over the Indo-Gangetic basin during the winter and summer seasons (2000-2005), Remote Sens. Environ., 107, 109-119, doi:10.1016/j.rse.2006.09.026.

Queface, A. J., et al. (2011), Climatology of aerosol optical properties in southern Africa, Atmos. Environ., 45, 2910-2921, doi:10.1016/j. atmosenv.2011.01.056

Quinn, P. K., et al. (2000), Surface submicron aerosol chemical composition: What fraction is not sulfate? J. Geophys. Res., 105, 6785-6805, doi:10.1029/1999JD901034.

Raizenne, M., et al. (1996), Health effects of acid aerosols on North American children: Pulmonary function, Environ. Health Perspect. 104, 506-514, doi:10.1289/ehp.96104506.

Reid, J. S., T. F. Eck, S. A. Christopher, P. V. Hobbs, and B. N. Holben (1999), Use of the Angstrom exponent to estimate the variability of optical and physical properties of aging smoke particles in Brazil, J. Geophys. Res., 104, 27,473-27,489, doi:10.1029/1999JD900833.

Roberts, G. C., M. O. Andreae, J. Zhou, and P. Artaxo (2001), Cloud condensation nuclei in the Amazon Basin: "Marine" conditions over a continent? Geophys. Res. Lett., 28, 2807-2810, doi:10.1029/ 2000GL012585.

Ross, K. E., S. J. Piketh, R. T. Bruintjes, R. P. Burger, R. J. Swap, and H. J. Annegarn (2003), Spatial and seasonal variation in $\mathrm{CCN}$ distribution and the aerosol-CCM relationship over southern Africa, J. Geophys. Res., 108(D13), 8481, doi:10.1029/2002JD002384.

Schuster, G. L., O. Dubovick, and B. N. Holben (2006), Angstrom exponent and bimodal aerosol size distributions, J. Geophys. Res., 111, D07207, doi:10.1029/2005JD006328.

Sievering, H. J., G. J. Boatman, W. Keene, Y. Kim, M. Luria, and J. Ray (1991), Heterogeneous sulfur conversion in sea-salt aerosol particles: The role of aerosol water content and size distribution, Atmos. Environ. Part A, 25, 1479-1487, doi:10.1016/0960-1686(91)90007-T.

Sivakumar, V., M. Tesfaye, W. Alemu, A. Sharma, C. Bollig, and G. Mengistu (2010), Aerosol measurements over South Africa using LIDAR, satellite and Sun photometer, Adv. Geosci., 16, 263-270.

Twomey, S. (1977), The influence of pollution on the shortwave albedo of clouds, J. Atmos. Sci., 34, 1149-1152, doi:10.1175/1520-0469(1977) 034<1149:TIOPOT>2.0.CO;2.

Tyson, P. D., and P. C. D'Abreton (1998), Transport and recirculation of aerosols off southern Africa: Macroscale plume structure, Atmos. Environ., 32, 1511-1524, doi:10.1016/S1352-2310(97)00392-0.

Tyson, P. D., M. Garstang, R. Swap, P. Kållberg, and M. Edwards (1996), An air transport climatology for subtropical southern Africa, Int. $J$ Climatol., 16, 265-291, doi:10.1002/(SICI)1097-0088(199603) $16: 3<265 *$ AID-JOC8 $>3$. . CO $2-\mathrm{M}$

Winkler, J., P. Formenti, D. J. Esterhuyse, R. J. Swap, G. Helas, H. J. Annegarn, and M. O. Andreae (2008), Evidence for large-scale transport of biomass burning aerosols from sunphotometry at a remote South African site, Atmos. Environ., 42, 5569-5578, doi:10.1016/j.atmosenv. 2008.03.031.

Zunckel, M., L. Robertson, P. D. Tyson, and H. Rodhe (2000), Modelled transport and deposition of sulphur over southern Africa, Atmos. Environ. 34, 2797-2808, doi:10.1016/S1352-2310(99)00495-1.

J. Botai, V. Sivakumar, and M. Tesfaye, Department of Geography, Geoinformatics and Meteorology, University of Pretoria, Pretoria 0002, South Africa. (mela 20062@yahoo.com; svenkataraman@csir.co.za)

G. Mengistu Tsidu, Department of Physics, Addis Ababa University, PO Box 1176, Addis Ababa, Ethiopia. 